\title{
Comparison of human and faunal enamel isotopes reveals diverse paleodiet and exchange patterns at the highland Maya Site of Kaminaljuyu, Guatemala
}

\author{
Ashley E. Sharpe ${ }^{1}$ (D ) Bárbara Arroyo ${ }^{2} \cdot$ Lori E. Wright ${ }^{3} \cdot$ Gloria Ajú $^{2} \cdot$ Javier Estrada $^{2} \cdot$ George D. Kamenov $^{4}$. \\ Emanuel Serech ${ }^{2} \cdot$ Emily Zavodny $^{5}$
}

Received: 6 September 2021 / Accepted: 22 December 2021 / Published online: 14 January 2022

This is a U.S. government work and not under copyright protection in the U.S.; foreign copyright protection may apply 2021

\begin{abstract}
This study provides an isotopic examination of both human and animal paleodiets and mobility patterns at a highland Maya community. Kaminaljuyu, Guatemala, was a large Prehispanic center located in a distinctly cooler, drier setting compared with the majority of Maya sites in the surrounding lowlands. Previous archaeological research at Kaminaljuyu revealed it played an important political and economic role in the Maya region, assisting in the obsidian trade network and maintaining ties with communities as far away as Teotihuacan in central Mexico. By examining the strontium $\left({ }^{87} \mathrm{Sr} /{ }^{86} \mathrm{Sr}\right)$, carbon $\left(\delta^{13} \mathrm{C}\right)$, and oxygen $\left(\delta^{18} \mathrm{O}\right)$ isotope values from dental enamel of humans and terrestrial mammals at the site, this study provides direct evidence of long-distance animal trade, explores the nature and timing of such activities, and compares highland dietary patterns with faunal studies in the lowlands. Our results indicate that isotopically non-local humans and animals are most frequently found in special and ceremonial contexts, indicating that long-distance movements of people and products were motivated for politically or ritually significant events. Although dietary patterns showed cross-species variation, diets within species were similar between highland and lowland settings.
\end{abstract}

Keywords Maya archaeology $\cdot$ Fauna $\cdot$ Stable isotopes $\cdot$ Paleodiet $\cdot$ Exchange $\cdot$ Mobility

\section{Introduction}

The past several decades of isotope research in the Maya area have produced many fascinating insights regarding the ecology, movements, and paleodiets of ancient humans and animals. These studies have used faunal diets as proxies for

Ashley E. Sharpe

SharpeAE@si.edu

1 Center for Tropical Paleoecology and Archaeology, Smithsonian Tropical Research Institute, 0843-03092 Balboa-Ancón, Republic of Panama

2 Proyecto Zona Arqueológica Kaminaljuyu, Zona 7, Guatemala City, Guatemala

3 Department of Anthropology, Texas A\&M University, College Station, TX, USA

4 Department of Geological Sciences, University of Florida, Gainesville, FL, USA

5 Department of Anthropology, University of Central Florida, Orlando, FL, USA landscape vegetation cover and its change over time (Emery et al. 2000; Emery and Thornton 2008; Sugiyama et al. 2020), and to better understand human diets and subsistence strategies (Gerry and Krueger 1997; Rand et al. 2020; White et al. 1993). They have been used to identify animal trade and management practices, necessary for sustaining large populations across a broad area (Freiwald and Pugh 2017; Rand et al. 2021; Sharpe et al. 2018; Thornton 2011; White et al. 2001, 2004). Isotope studies on human and animal remains have also been used with other archaeological datasets to interpret differences in social status and resource distribution in the Maya region (Price et al. 2008, 2010; Somerville et al. 2016; Wright 2012; Wright et al. 2010).

The present study provides the first isotopic dataset using tooth enamel from fauna at a Maya highland site, providing a unique ecological and social setting for comparison with preexisting data from other areas. Kaminaljuyu was the largest Prehispanic highland community in the Maya region, with a long occupation beginning around $800 \mathrm{BCE}$ (Figs. 1, 2). The site was a politically powerful settlement and ceremonial center that participated in highland exchange 
Fig. 1 Map of the Maya region and sites referred to in this study. Strontium isotope ranges based on Freiwald et al. (2020), Hodell et al. (2004), and Price et al. $(2008,2019)$. Note the Metamorphic Province contains the Motagua Valley, with a ${ }^{87} \mathrm{Sr} /{ }^{86} \mathrm{Sr}$ range of $0.07042-$ 0.7073 . Values exceeding this range in the Metamorphic Province are not common based on current isoscape data

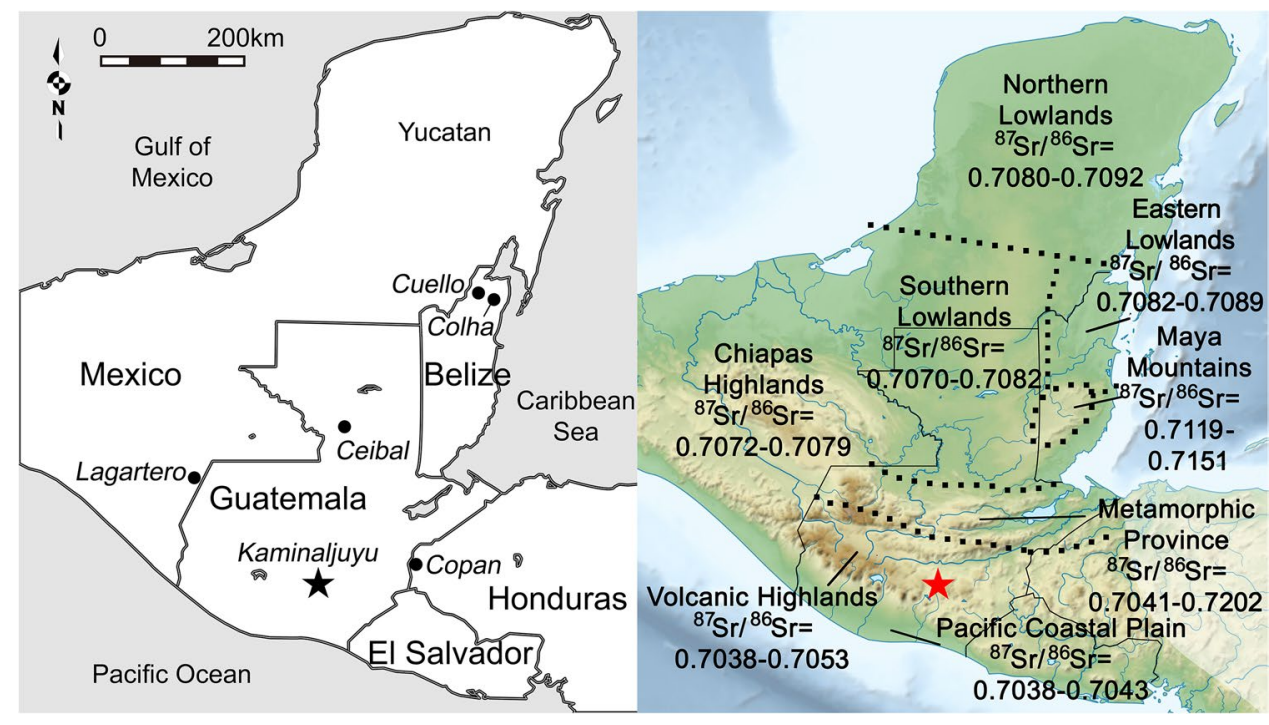

Fig. 2 Map and chronological timeline of Kaminaljuyu, Guatemala. Map courtesy of the Proyecto Zona Arqueológica Kaminaljuyu

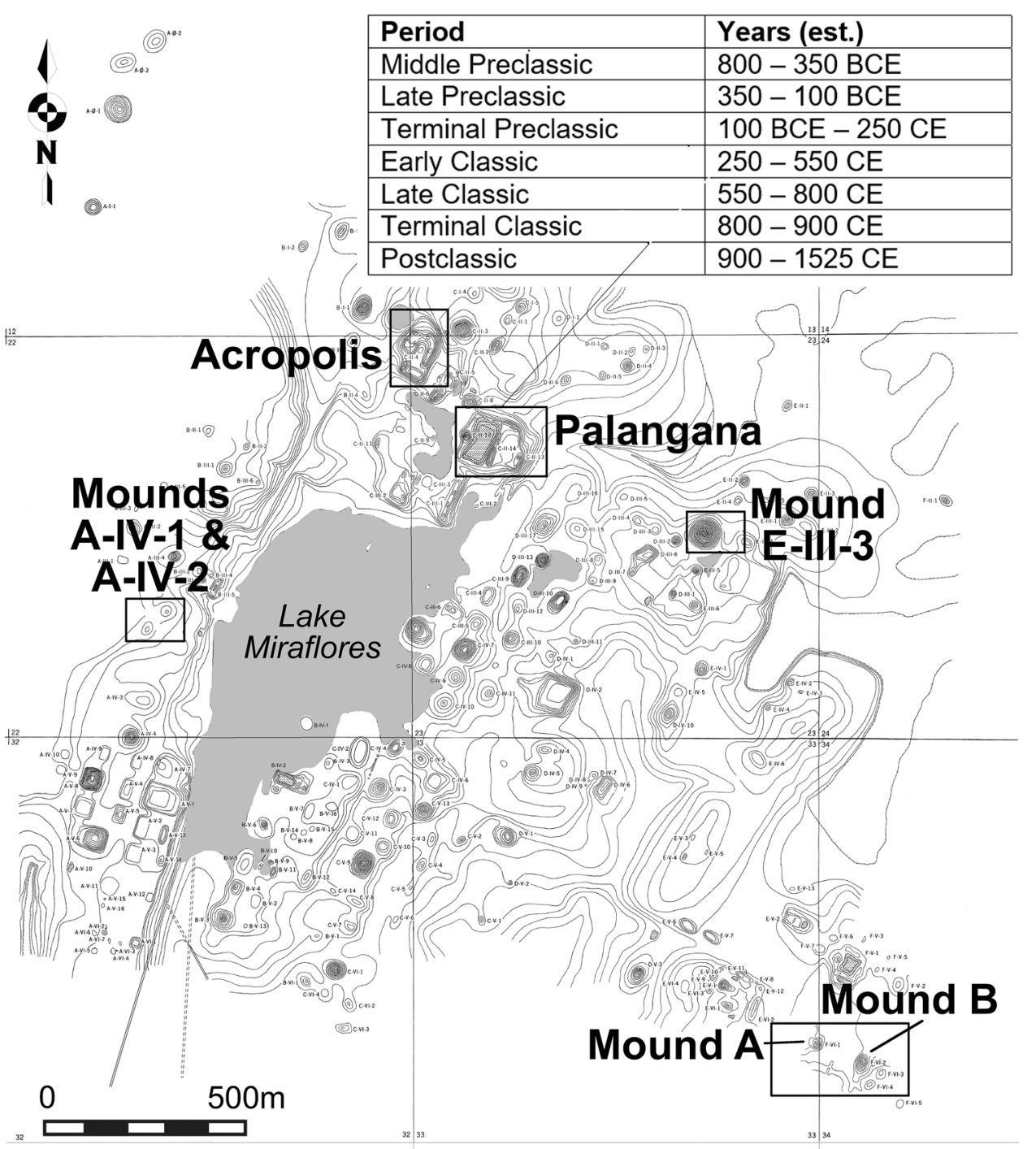


networks, including that of obsidian, a local resource that was exchanged broadly throughout the surrounding lowlands (Arroyo et al. 2020; Kaplan 2011; Popenoe de Hatch 2002). Previous isotope studies at Kaminaljuyu have focused on human remains recovered from burial deposits (Valdés and Wright 2004; White et al. 2000; Wright 2013; Wright and Schwarcz 1998, 1999; Wright et al. 2010). These studies identified remarkable dietary consistency among those individuals who were born locally at or near the site. They also discovered that non-local individuals were often incomplete skeletons or isolated crania placed in larger tombs containing locally-born central occupants.

Our study set out to address five main questions: (1) Can we identify the remains of non-local fauna at Kaminaljuyu using stable isotope analyses that would indicate the exchange of whole or parts of individual animals? (2) If nonlocal animals are identified, in what contexts are they found, and how does this compare with the contexts in which nonlocal humans have been identified at Kaminaljuyu? (3) Does the presence of non-local animals align chronologically with the arrival of non-local human individuals, and do they come from the same geographic points of origin? (4) What was the nature of animal diets at Kaminaljuyu, and how similar were the faunal diets to the diets of humans previously tested at the site? (5) Using animal diets as a proxy for local environment, how do fauna differ isotopically between Kaminaljuyu and the Maya lowlands?

We anticipated that the answers to these questions would provide important information regarding Kaminaljuyu's ecology, subsistence practices, and relationship with the surrounding Maya region. The results, however, show considerable variation in species' diets, as well as place of origin when comparing non-local humans and animals. While we do identify non-local animals, they included small-bodied mammals that are not generally considered to have been trade items (i.e., pocket gophers). In addition to providing information about the diets and exchange activities among the ancient highland Maya, this study also serves as a warning against the assumption that small mammals recovered at a site were locally acquired. Rather, ceremonial activities appear to have been a driving factor in the movement of animals, and perhaps humans as well, across the landscape.

\section{History of Kaminaljuyu and past research}

Kaminaljuyu is located underneath the modern metropolis of Guatemala City, which has dramatically altered the original landscape and settlement features. The surrounding highland region has an elevation between 1000 to 4220 masl and is characterized by steep valleys, ridges, and numerous volcanoes (Islebe et al. 1995). Vegetation ranges from tropical humid forests in the lowest valleys to mixed conifer and broadleaf forest on the mountain slopes. Dry scrubland covers the highest elevations. The earliest evidence for human occupation at Kaminaljuyu dates to c. $800 \mathrm{BCE}$, with settlement focused around the area that was once Lake Miraflores (Fig. 2; Arroyo et al. 2020).

The settlement expanded over the ensuing centuries, and by the Terminal Preclassic period (100 BCE-250 CE), Kaminaljuyu had become the dominant political center in the region. Archaeologists have uncovered the remains of extensive canal and irrigation systems around the original lake, attesting to the settlement's dependence on agricultural activities (Valdés and Popenoe de Hatch 1996; Valdés 1997; Valdés and Wright 2004:340-341). Kaminaljuyu's rulers maintained political authority in part through an extensive trade network that relied on obsidian exchange out of the highlands. These rulers also promoted ceremonial activities that fostered unity within the community and connected it to similar ritual displays of power elsewhere in the Maya area (Inomata et al. 2014; Kaplan 2002, 2011; Popenoe de Hatch 2002). By the Early Classic period (250-550 CE), Kaminaljuyu's power began to waver, partly due to the ecological decline brought about by the slow diminishment of the lake. Several large royal tombs dating to this era, along with the construction of elite temples in the talud-tablero style of central Mexico, suggest that Kaminaljuyu maintained political ties with both lowland Maya centers and distant Teotihuacan (Arroyo et al. 2020; Braswell 2003). Yet by the Terminal Classic period (800-900 CE), Kaminaljuyu's population had considerably declined. The site was only intermittently occupied thereafter until the arrival of the Spanish.

Excavations have been ongoing to preserve Kaminaljuyu's archaeological history since the early twentieth century, in spite of the gradual development of the modern metropolis over the original settlement (Kidder 1945; Kidder et al. 1946). Wright, Schwarcz, and colleagues (Wright and Schwarcz 1998, 1999; Wright et al. 2010) conducted the first stable isotope studies at the site, focusing on teeth from human burials recovered from excavations from the preceding decades. These burials included several large Early Classic elite tombs in Mounds A and B excavated by Kidder et al. (1946) at the southeast margin of the site (Fig. 2). Some of these contained the remains of a principal occupant surrounded by other individuals who may have been sacrificed or were secondary burials of earlier tomb occupants. Other burials that were included in the analysis came from rescue projects in the residential areas (Valdés and Wright 2004) and a series of ceremonial structures that included the Acropolis and Palangana (a ceremonial platform with an upraised eastern side and lower western side, first excavated by Pennsylvania State University; Michels and Sanders 1973). These deposits primarily dated to the Early Classic period, with a few coming from earlier and later contexts. 
Osteological analysis of the human remains was conducted by Wright (Valdés and Wright 2004; Wright et al. 2010). For the isotope analysis, teeth from 42 individuals were selected based on the preservation of the skeleton and secure contextual information (see Wright et al. 2010 for details). Isotope ratios were obtained on representative enamel sections from first molars, premolars, and third molars. The majority of individuals came from the Mounds A and B structures excavated by Kidder et al. (1946), residential structures excavated by the Proyecto Miraflores II, and a few from the Early Classic phases of the Palangana excavated by Penn State (Wright et al 2010:Table 2). One of the primary goals of the isotope study was to compare the diets and place of origin of the remains in the Mound A and B tombs with burials from other parts of the site.

The human isotope data show that the majority of individuals buried at Kaminaljuyu were likely born locally. A few individuals, including isolated skulls and adolescent individuals placed within primary elite burials, were from other regions. There was little pattern exhibited among the latter, although some appear to have come from an area to the northeast of Kaminaljuyu, with elevated oxygen and strontium isotope values more closely resembling the Caribbean side of the highlands. One adolescent skull had a particularly high strontium value (Tomb A-III, Skull 1, $\left.{ }^{87} \mathrm{Sr} /{ }^{86} \mathrm{Sr}=0.71050\right)$, indicating it may have come from the Maya Mountains of south-central Belize. The present study uses these results to interpret local and non-local isotope values in the faunal remains.

Animals sampled in the present study come from four parts of the site (Fig. 2), which have been excavated from 2010 to 2016 by the Proyecto Zona Arqueológica Kaminaljuyu (ZAK, Kaminaljuyu Archaeological Zone Project), directed by Bárbara Arroyo. The first two of these locations include the Acropolis and Palangana. ZAK excavations in the Palangana recovered a series of dense concentrations of miscellaneous artifacts, burnt organic material, human remains, and animal bones that mainly consisted of dogs (Ajú Álvarez 2017; Sharpe et al. 2022). These deposits date to the Terminal Preclassic period, and may have been closely related in time (they were designated as the "Gran Depósito" or Great Deposit by the excavators, but it is unclear if they were a single deposit). The third location in this study is the base of Mound E-III-3, once the largest structure at the site before it was destroyed during a development project in the mid-twentieth century (Shook and Kidder 1952). Recent excavations located thousands of intentionally shattered ceramic vessels at the base of this structure, which had likely been a form of Late Preclassic dedicatory offering intentionally laid before the structure's construction (Estrada de la Cerda 2017). The deposit included the remains of several humans (some either disturbed or intentionally disarticulated before deposition), as well as considerable quantities of ash from burned organic material and animal bones. The animal remains mainly consisted of deer, dogs, and thousands of fish bones, some of which could be identified to marine species (Lutjanus sp. and Dormitator latifrons; Sharpe et al. 2022). The fourth location included in the study was the area around Mounds A-IV-1 and A-IV-2. This area is believed to have served several functions during the Late Preclassic through Early Classic periods, including for storage and for small cache and burial deposits (Serech van Haute 2018). It may have been near a residential area, which is now covered by the modern city and impossible to access. Animals from this part of the site came from midden and fill deposits.

\section{Stable isotope methods in Maya zooarchaeology}

This study uses a combination of stable isotopic ratios to determine animal diet and movement in the past. To assess diet, carbon isotopes from dental enamel $\left(\delta^{13} \mathrm{C}_{\mathrm{en}}\right)$ are used to determine what animals ate during enamel development. Oxygen $\left(\delta^{18} \mathrm{O}_{\mathrm{en}}\right)$ and strontium $\left({ }^{87} \mathrm{Sr} /{ }^{86} \mathrm{Sr}\right)$ isotopes are used to identify which individuals were non-local to the highlands and gauge from where they may have originally come.

Many studies of human and animal paleodiet in the Maya region have relied on bone collagen, since collagen contains the isotopic composition of the last several years of an individual's diet (Hedges et al. 2007; Matsubayashi and Tayasu 2019). However, collagen preservation is poor throughout much of the volcanic highlands and Pacific coast. Occasionally, the only remaining portion of a human burial is the outline of the original deposit with a few teeth that managed to preserve longer than the rest of the skeleton (Renson et al. 2019; Wright and Schwarcz 1999). Although a small number of human bone and dentin samples were successfully extracted by Wright et al. (2010), the majority of human dietary data was gathered from tooth enamel $\delta^{13} \mathrm{C}$. Therefore, we focused this study on animal teeth and on the best-preserved specimens. This allows us to examine how similar the non-human animal and human diets were at the site. Animals raised in captivity, such as domestic dogs, might be expected to have diets that resemble those of humans (Guiry 2012; White et al. 2001). Animals that were presumably caught in the wild, such as the deer and gophers in this study, should have isotope values that reflect the local habitat.

The $\delta^{13} \mathrm{C}$ isotopes in dental enamel reflect the diet of an animal during the time of tooth development, particularly during the first several months of life for most mammals in this study. The $\delta^{13} \mathrm{C}$ of hypselodont incisors, like the pocket gophers (Orthogeomys hispidus) reported here, represent a longer range of time because these teeth continuously grow throughout life (Jernvall and Thesleff 2012). Carbon 
isotope ratios can determine whether an animal was consuming predominantly plants with $\mathrm{a}_{3}$ photosynthetic pathway, which includes most leafy vegetation in the Maya area, to plants with a $\mathrm{C}_{4}$ photosynthetic pathway, which includes grasses such as maize (DeNiro and Epstein 1978; van der Merwe 1982). Modern $C_{3}$ plants usually have $\delta^{13} \mathrm{C}$ values that range from $\sim-33$ to $-24 \%$ in the Maya area, whereas $\mathrm{C}_{4}$ plants like maize have a $\delta^{13} \mathrm{C}$ range of $\sim-12$ to $-10 \%$ o (White et al. 2001, 2004), even in the highlands (Wright et al. 2010:Table 4). Among humans in Prehispanic Mesoamerica, $\delta^{13} \mathrm{C}$ is typically used to determine the amount of maize in the diet since maize was the principal edible $\mathrm{C}_{4}$ plant in the region. There is no evidence that other tropical grasses (e.g., Chloridoideae, Panicoideae) contributed significantly to Maya diets, and many cannot be digested by humans. Crassulacean acid metabolism (CAM) plants, including cacti, can provide $\delta^{13} \mathrm{C}$ values between those of $\mathrm{C}_{3}$ and $\mathrm{C}_{4}$ plants (O'Leary 1981). However, they are also not considered to have contributed sufficiently to Maya diets to shift $\delta^{13} \mathrm{C}$ values in humans.

Non-human animal diets, however, typically differ substantially from those of humans. Isotope studies in Mesoamerica, as well as modern food web studies and feeding experiments, have indicated that mammals that regularly consume maize from a young age will have elevated $\delta^{13} \mathrm{C}$ values (e.g., Ambrose and Norr 1993; Darr and Hewitt 2008; Kays and Feranec 2011; Tieszen and Fagre 1993). However, herbivores that opportunistically feed on maize or other grasses, as well as omnivores or carnivores that consume these herbivores, have intermediary $\delta^{13} \mathrm{C}$ values (Cormie and Schwarcz 1994; Sharpe et al. 2018; Thornton et al. 2016). Habitat disturbance for the establishment of agricultural fields and dwellings tends to produce more secondary grassland environments that could elevate $\delta^{13} \mathrm{C}$ in grazing animals. While forest clearing and the spread of grasslands has been identified with isotopes in areas outside the Maya area, such as central Panama (Sugiyama et al. 2020), it has yet to be conclusively documented in the Maya region (see Emery and Thornton 2008 for a review).

To address the matter of whether animals were moved to Kaminaljuyu, as either live individuals or deceased products (e.g., food, adornments, ritual items), this study uses strontium $\left({ }^{87} \mathrm{Sr} /{ }^{86} \mathrm{Sr}\right)$ and oxygen $\left(\delta^{18} \mathrm{O}\right)$ isotopes from dental enamel. Since enamel develops once in the life of most mammals (excepting the hypselodont gophers in this study), it can be used to determine the origin of an individual by comparing the ${ }^{87} \mathrm{Sr} /{ }^{86} \mathrm{Sr}$ and $\delta^{18} \mathrm{O}$ of the enamel to the expected local range of these isotopes. Strontium isotopes vary by geographic region based on rock type, age, and the history of weathering in an area (Bentley 2006; Price et al. 2002). Geological sources of strontium enter the food and water that animals consume in a particular area, and strontium becomes incorporated in dental enamel. Typically resistant to diagenetic exchange, tooth enamel retains the original ${ }^{87} \mathrm{Sr} /{ }^{86} \mathrm{Sr}$ signature from the time it was developed. Several regional ${ }^{87} \mathrm{Sr} /{ }^{86} \mathrm{Sr}$ baselines have been established for the Maya and surrounding regions (Hodell et al. 2004; Miller Wolf and Freiwald 2018; Price et al. 2008; Thornton 2011). Hodell et al. (2004) determined that the highlands around Kaminaljuyu have ${ }^{87} \mathrm{Sr} /{ }^{86} \mathrm{Sr}$ of $\sim 0.70417$ (15 samples, s.d. $\left.=2 \times 10^{-4}\right)$, and Wright et al. (2010:159) determined the Valley of Guatemala, where Kaminaljuyu is located, has a value of $\sim 0.7045$.

Oxygen isotope values in teeth function similarly to strontium isotope ratios, in that they are set during enamel formation and can be matched with expected local ranges. However, $\delta^{18} \mathrm{O}_{\mathrm{en}}$ in animals varies due to a number of environmental, behavioral, and physiological circumstances, making it less predictable for assessing location of origin than ${ }^{87} \mathrm{Sr} /{ }^{86} \mathrm{Sr}$. The oxygen isotope content in terrestrial mammal hydroxyapatite generally derives from water, with a smaller contribution from food and from breathing atmospheric $\mathrm{O}_{2}$ (Pederzani and Britton 2019; Sponheimer and Lee-Thorp 1999). Non-obligate drinking herbivores obtain most of their water from vegetation. For example, white-tailed deer (Odocoileus virginianus) bone $\delta^{18} \mathrm{O}$ is primarily dependent on the $\delta^{18} \mathrm{O}$ of leaves from which they obtain water (Repussard et al. 2014). Surface water $\delta^{18} \mathrm{O}$ in the Maya area is primarily influenced by the $\delta^{18} \mathrm{O}$ of rain, with the Caribbean coast having the highest $\delta^{18} \mathrm{O}$ values ( - 4 to $-1 \%$ ) and the Guatemalan highlands and Pacific coast having the lowest $\delta^{18} \mathrm{O}$ values ( -6 to $-4 \%$ in the highlands, - 10 to $-6 \%$ along the Pacific coast; Brenner et al. 2003; Lachniet and Patterson 2009). However, $\delta^{18} \mathrm{O}$ also varies among local water sources, particularly smaller closed bodies of waters such as swamps and ponds, due to differences in evaporative enrichment throughout the year and variations and rainfall (Brenner et al. 2003; Scherer et al. 2015; Wright 2017). Skeletal mineral $\delta^{18} \mathrm{O}$ is also shaped by the metabolic differences among different species, as fractionation in hydroxyapatite mineralization is temperature dependent, and mammals differ in body temperatures. The $\delta^{18} \mathrm{O}$ of water sources differ considerably between obligate and non-obligate drinkers (Bryant and Froelich 1995; Pietsch et al. 2011; Repussard et al. 2014). The local range of $\delta^{18} \mathrm{O}$ in meteoric water around Kaminaljuyu should be around -6 to $-4 \%$ (Lachniet and Patterson 2009; Wright et al. 2010), but we would expect some variation based on differences in animal metabolism and drinking behavior.

\section{Methods}

Faunal specimens used in the present study (Table 1) were selected based on quality of preservation and whether they came from securely-dated contexts. Most teeth were recovered as either isolated specimens or as part of a mandible or cranium. In no case was a complete, articulated 
skeleton recovered, although the Mound E-III-3 and Palangana deposits contained partially articulated dogs, gophers, and small birds, which may have been offerings, feasting remains, or both (Sharpe et al. 2022). All specimens were photographed and measured prior to isotope analysis. Initial selection, cleaning, and drilling of enamel samples were performed in the Archaeological Laboratories of the Smithsonian Tropical Research Institute in Panama City, Panama. Enamel processing for strontium isotopes was performed in the class 100 clean labs of the University of Florida Department of Geological Sciences in Gainesville, FL, USA.
Detailed procedures used in the pretreatment and processing of specimens follow methods reported in Sharpe et al. (2018). Enamel was carefully extracted and cleaned from surface contaminants and dentin with a Dedeco carbide blade and a diamond-tipped Brasseler NSK Z500 drill, using different drill heads to avoid cross-contamination. Approximately $20-50 \mathrm{mg}$ of enamel was obtained from each tooth. Half of the sample was ground and placed in individual sterile microcentrifuge tubes to be used for the $\delta^{13} \mathrm{C}$ and $\delta^{18} \mathrm{O}$ analysis. About $2 \mathrm{ml}$ of $2.5 \%$ sodium hypochlorite $(\mathrm{NaOCl})$ was added to each tube and set for $16 \mathrm{~h}$, with intermittent

Table 1 Enamel specimens tested for carbon, oxygen, and strontium isotopes in this study. LP Late Preclassic, TP Terminal Preclassic, EC Early Classic, $C$ Classic (mostly Late)

\begin{tabular}{|c|c|c|c|c|c|c|}
\hline Specimen number & $\begin{array}{l}\text { Chronological } \\
\text { period }\end{array}$ & Area of site & Common name & $\begin{array}{l}\delta^{13} \mathrm{C}_{\mathrm{en}}(\% o, \text { vs. } \\
\mathrm{PDB})\end{array}$ & $\begin{array}{l}\delta^{18} \mathrm{O}_{\mathrm{en}}(\% o, \text { vs. } \\
\mathrm{PDB})\end{array}$ & ${ }^{87} \mathrm{Sr} /{ }^{86} \mathrm{Sr}$ \\
\hline EN-01 & LP & Mound A-IV-1/A-IV-2 & Domestic dog & -3.40 & -5.91 & 0.704183 \\
\hline $\mathrm{EN}-02$ & LP & Mound E-III-3 & Domestic dog & -3.67 & -5.17 & 0.706915 \\
\hline EN-03 & LP & Mound E-III-3 & Domestic dog & -2.71 & -6.37 & 0.704375 \\
\hline EN-04 & LP & Mound E-III-3 & Hispid pocket gopher & -7.52 & -6.27 & 0.707535 \\
\hline EN-05 & LP & Mound E-III-3 & Hispid pocket gopher & -4.64 & -8.87 & 0.704033 \\
\hline EN-06 & LP & Mound E-III-3 & Hispid pocket gopher & -10.73 & -4.80 & 0.705980 \\
\hline EN-07 & $\mathrm{TP}$ & Mound A-IV-1/A-IV-2 & Domestic dog & -1.37 & -5.25 & 0.704168 \\
\hline $\mathrm{EN}-08$ & $\mathrm{TP}$ & Palangana & Domestic dog & -0.90 & -6.89 & 0.704152 \\
\hline EN-09 & $\mathrm{TP}$ & Palangana & Domestic dog & -3.77 & -5.45 & 0.704715 \\
\hline EN-10 & $\mathrm{TP}$ & Palangana & Domestic dog & -2.74 & -4.87 & 0.704761 \\
\hline EN-11 & $\mathrm{TP}$ & Palangana & Hispid pocket gopher & - & - & 0.704139 \\
\hline $\mathrm{EN}-12$ & $\mathrm{TP}$ & Palangana & Domestic dog & -1.29 & -6.07 & 0.704133 \\
\hline $\mathrm{EN}-13$ & $\mathrm{TP}$ & Palangana & Domestic dog & 0.47 & -6.42 & 0.704540 \\
\hline EN-14 & $\mathrm{TP}$ & Palangana & Domestic dog & -1.63 & -5.89 & 0.704811 \\
\hline EN-15 & $\mathrm{TP}$ & Palangana & Domestic dog & -0.01 & -5.54 & 0.704222 \\
\hline EN-16 & $\mathrm{TP}$ & Palangana & Domestic dog & -0.51 & -6.52 & 0.704314 \\
\hline EN-17 & $\mathrm{TP}$ & Palangana & Domestic dog & 1.57 & -5.49 & 0.704138 \\
\hline $\mathrm{EN}-18$ & TP & Palangana & Domestic dog & -1.54 & -7.00 & 0.706535 \\
\hline EN-19 & $\mathrm{TP}$ & Palangana & Domestic dog & -6.29 & -4.55 & 0.704401 \\
\hline EN-20 & $\mathrm{TP}$ & Palangana & Domestic dog & 0.41 & -5.20 & 0.705531 \\
\hline $\mathrm{EN}-21$ & $\mathrm{TP}$ & Palangana & Domestic dog & -0.22 & -5.51 & 0.704416 \\
\hline $\mathrm{EN}-22$ & $\mathrm{TP}$ & Palangana & Hispid pocket gopher & -10.35 & -7.93 & 0.704070 \\
\hline $\mathrm{EN}-23$ & $\mathrm{TP}$ & Palangana & Hispid pocket gopher & -11.55 & -6.14 & 0.704107 \\
\hline EN-24 & $\mathrm{TP}$ & Palangana & Hispid pocket gopher & -7.94 & -7.27 & 0.704261 \\
\hline $\mathrm{EN}-25$ & $\mathrm{TP}$ & Palangana & Hispid pocket gopher & -1.29 & -5.13 & 0.703792 \\
\hline $\mathrm{EN}-26$ & $\mathrm{TP}$ & Palangana & Hispid pocket gopher & -12.39 & -4.86 & 0.704049 \\
\hline $\mathrm{EN}-27$ & $\mathrm{EC}$ & Palangana & Domestic dog & 0.09 & -6.55 & 0.704391 \\
\hline $\mathrm{EN}-28$ & $\mathrm{EC}$ & Palangana & Domestic dog & -0.09 & -5.80 & 0.704025 \\
\hline $\mathrm{EN}-29$ & $\mathrm{EC}$ & Mound A-IV-1/A-IV-2 & Deer (white-tailed?) & -13.81 & -6.48 & 0.704079 \\
\hline $\mathrm{EN}-30$ & $\mathrm{EC}$ & Palangana & Deer (white-tailed?) & -13.46 & -3.91 & 0.707898 \\
\hline EN-31 & $\mathrm{C}$ & Acropolis & Domestic dog & -0.09 & -6.88 & 0.704252 \\
\hline EN-32 & $\mathrm{C}$ & Acropolis & Domestic dog & -0.21 & -6.16 & 0.704242 \\
\hline EN-33 & $\mathrm{C}$ & Acropolis & Domestic dog & 0.63 & -6.30 & 0.704261 \\
\hline EN-34 & $\mathrm{C}$ & Acropolis & Domestic dog & -6.62 & -5.02 & 0.704460 \\
\hline EN-35 & $\mathrm{C}$ & Acropolis & Hispid pocket gopher & -9.48 & -7.30 & 0.703996 \\
\hline
\end{tabular}


agitation. The samples were then rinsed to neutral $\mathrm{pH}$ with distilled-deionized water $\left(\mathrm{DI}-\mathrm{H}_{2} \mathrm{O}\right)$, and $\sim 2 \mathrm{ml}$ of $0.2 \mathrm{M}$ acetic acid $\left(\mathrm{C}_{2} \mathrm{H}_{4} \mathrm{O}_{2}\right)$ was added and again set for $16 \mathrm{~h}$ with intermittent agitation. The samples were rinsed to neutral $\mathrm{pH}$ a second time, excess DI- $\mathrm{H}_{2} \mathrm{O}$ was removed, and the samples were frozen and freeze dried for 2-3 days. Samples were weighed and then measured for $\delta^{13} \mathrm{C}$ and $\delta^{18} \mathrm{O}$ at the Light Stable Isotope Mass Spectrometry Laboratory at the University of Florida on a Kiel III carbonate prep device connected to a Finnegan MAT 252 isotope ratio mass spectrometer. The precision using the NBS-19 standard was $\sim 0.02 \%$ ofor $\delta^{13} \mathrm{C}$ and $\sim 0.04 \%$ or $\delta^{18} \mathrm{O}$.

The second half of the enamel sample was used for ${ }^{87} \mathrm{Sr} /{ }^{86} \mathrm{Sr}$ analysis. Samples were placed in precleaned Teflon vials with $2 \mathrm{ml}$ of $8 \mathrm{~N}$ nitric acid $\left(\mathrm{HNO}_{3}\right.$, Optima). Small amounts of solution $(<100 \mathrm{ml}$, variable depending on original sample weight) of each were removed to test for strontium concentrations on an Element2 HR-ICP-MS, following methods described by Kamenov et al. (2018). The remaining solution was evaporated on a hot plate at $100{ }^{\circ} \mathrm{C}$. The strontium was separated using ion chromatography, using a strontium-selective crown ether resin (Sr-spec; Eichrom Technologies) and multiple washes of $3.5 \mathrm{M} \mathrm{HNO}_{3}$ (Pin and Bassin 1992). Samples were measured on a NuPlasma multiple collector inductively coupled plasma mass spectrometer (MC-ICP-MS), and the NBS 987 average was 0.710241 $(2 \sigma=0.00003)$.

\section{Results and discussion}

A total of 35 samples were included in the analysis: 23 from dogs, two from deer, and ten from gophers (Table 1; Online Resource 1). Although teeth were available from rabbits
(Sylvilagus floridanus) and opossums (Didelphidae), they were too fragile to test. All animals tested were identified as adult or older subadult individuals. Twenty specimens came from Terminal Preclassic deposits, since these were the foci of excavations in recent years. A smaller number of Early Classic and mixed (likely Late or Terminal) Classic specimens were also included, providing an overview of animal isotope values over the course of a thousand years.

\section{Exchange of animals to Kaminaljuyu: enamel ${ }^{87} \mathrm{Sr} /{ }^{86} \mathrm{Sr}$ and $\delta^{18} \mathrm{O}$}

Comparison of the strontium and oxygen isotope values at Kaminaljuyu in Fig. 3 shows that five animals we sampled had ${ }^{87} \mathrm{Sr} /{ }^{86} \mathrm{Sr}$ values that could be considered as statistical outliers $\left({ }^{87} \mathrm{Sr} /{ }^{86} \mathrm{Sr}\right.$ mean 0.70468 , s.d. $\left.=1.03 \times 10^{-3}\right)$. Since prior studies using geologic samples from Kaminaljuyu and the immediate area have identified ${ }^{87} \mathrm{Sr} /{ }^{86} \mathrm{Sr}$ values below 0.7050 (Hodell et al. 2004; Wright et al. 2010), a sixth sample $\left({ }^{87} \mathrm{Sr} /{ }^{86} \mathrm{Sr}=0.70553\right)$ might also be considered nonlocal to Kaminaljuyu but perhaps from a nearby highland area. The majority of the fauna has local ${ }^{87} \mathrm{Sr} /{ }^{86} \mathrm{Sr}$ values, and includes most of the dogs from the Palangana deposits, as well as all of the Late Classic animals. All twenty of the dogs that had "local" strontium isotope ratios also had $\delta^{18} \mathrm{O}_{\text {en }}$ values below $-4.5 \%$, a range that would be expected for humans living in the highlands.

Four of the gophers that had local ${ }^{87} \mathrm{Sr} /{ }^{86} \mathrm{Sr}$ values had $\delta^{18} \mathrm{O}_{\mathrm{en}}$ values lower than $-7 \%$, which would be expected from humans originating from the Pacific coastal plain (Price et al. 2008; Renson et al. 2019; Wright et al. 2010). However, these low $\delta^{18} \mathrm{O}_{\mathrm{en}}$ values may be due to a metabolic or dietary habit unique to gophers. Isotopic data on modern gophers is lacking; however, paleoecological studies from
Fig. 3 Strontium and oxygen isotope values for human and fauna enamel at Kaminaljuyu. In cases where more than one human tooth was tested, only the first molar is represented except for individual KJ54, where the third molar differed more from the expected local strontium range $(\sim 0.7040$ $0.7050)$ than the first molar

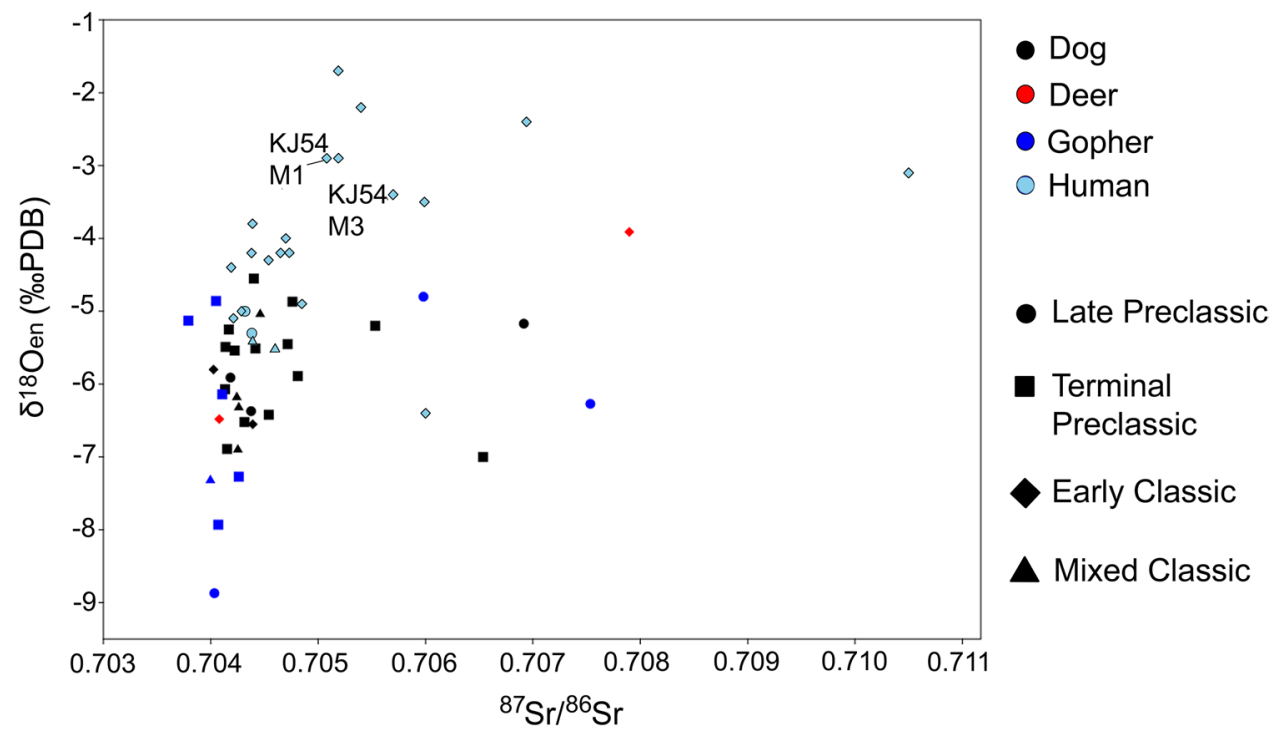


North American species have found that gophers with similarly low oxygen isotope values occur among individuals living in cooler environments (Rogers and Wang 2002). A similar pattern has been observed recently in the bone carbonate $\delta^{18} \mathrm{O}$ from leporids (rabbits and jackrabbits) when compared across different habitats in northern Mexico (Somerville et al. 2018, 2020). Like gophers, rabbits obtain much of their water through vegetal matter, and their $\delta^{18} \mathrm{O}$ values often reflect local precipitation and temperature. Rabbits from cooler, wetter highland regions had lower bone carbonate $\delta^{18} \mathrm{O}$ values. The gophers with low $\delta^{18} \mathrm{O}_{\text {en }}$ values were from several different deposits and ranged from Late Preclassic through Classic periods (Table 2), indicating there was no change over time in local conditions.

The six distinctly non-local specimens include three dogs, two gophers, and one deer. Two of these dogs come from the Terminal Preclassic Palangana deposits. These had ${ }^{87} \mathrm{Sr} /{ }^{86} \mathrm{Sr}$ values of 0.70553 and 0.70654 , indicating they had different locations of origin. The dog with the higher strontium value perhaps came from an area with a less volcanic or more mixed geologic strontium signature. The $\delta^{18} \mathrm{O}_{\mathrm{en}}$ of this dog is lower than any other $(-7.0 \%)$. Such a low $\delta^{18} \mathrm{O}_{\mathrm{en}}$ value indicates isotopically light precipitation, such as occurs on the Pacific coast of Guatemala (Lachniet and Patterson 2009). This suggests the dog may be from another area of the highlands with more variable geology, either to the north (northwest Guatemala or Chiapas) or south (El Salvador or Honduras; for a discussion on the $\mathrm{Sr}$ variability in the latter, see Miller Wolf and Freiwald 2018). A second dog has a $\delta^{18} \mathrm{O}_{\text {en }}$ value of $-5.2 \%$, within the range of the dogs that have local ${ }^{87} \mathrm{Sr} /{ }^{86} \mathrm{Sr}$. This dog may well have been raised in another area of the Guatemalan highlands with a slightly higher strontium ratio than Kaminaljuyu.

The third non-local dog had ${ }^{87} \mathrm{Sr} /{ }^{86} \mathrm{Sr}$ of 0.70692 and $\delta^{18} \mathrm{O}_{\mathrm{en}}$ of $-5.2 \%$. The tooth came from a disarticulated but mostly complete individual found in the dense Late Preclassic dedicatory offering of human remains and shattered ceramic vessels at the base of Mound E-III-3. As was mentioned, this deposit contained hundreds of fish bones, some identified as marine species. At least one species is from the Pacific coast (the Pacific sleeper, Dormitator latifrons). The only shell species in the assemblage is also from the Pacific coast (an ark clam, Anadara tuberculosa). However, the non-local dog's strontium isotope value does not match that of the Pacific coastal plain, nor does its $\delta^{18} \mathrm{O}_{\mathrm{en}}$ value; it appears to come from somewhere to the east, such as the region of metamorphic geology around and including the Motagua Valley of central Guatemala and western Honduras (Hodell et al. 2004). The underlying bedrock of these zones is geologically complex, and is neither dominated by the volcanic alluvium from the highlands as observed on the Pacific coastal plain (resulting in low ${ }^{87} \mathrm{Sr} /{ }^{86} \mathrm{Sr}$ ), nor the karstic bedrock of northern Guatemala, Belize, and southern Mexico $\left({ }^{87} \mathrm{Sr} /{ }^{86} \mathrm{Sr}\right.$ typically above 0.7073 ; Hodell et al. 2004:588).

Of the two deer teeth tested, one was local to Kaminaljuyu, and the other had strontium and oxygen values that were clearly not from the highlands. The strontium value (0.70790) matches the primarily Cretaceous/Paleocene limestone of southern Mexico, northern Guatemala, or western Belize. The oxygen value $(-3.9 \%$ ) matches these areas as well. The deer tooth was one of several fragmented molars from a poorly preserved mandible found
Table 2 Descriptive statistics of the carbon and oxygen isotope values by chronological period

\begin{tabular}{|c|c|c|c|c|c|c|}
\hline \multirow[t]{2}{*}{ Tooth and period } & \multicolumn{3}{|c|}{$\delta^{13} \mathrm{C}_{\mathrm{en}}$} & \multicolumn{3}{|c|}{$\delta^{18} \mathrm{O}_{\mathrm{en}}$} \\
\hline & Mean & $\mathrm{sd}$ & Range & Mean & sd & Range \\
\hline \multicolumn{7}{|l|}{ Late Preclassic } \\
\hline Dogs (3) & -3.3 & 0.5 & -3.7 to -2.7 & -5.8 & 0.6 & -6.4 to -5.2 \\
\hline Gophers (3) & -7.6 & 3.0 & -10.7 to -4.6 & -6.7 & 2.1 & -8.9 to -4.8 \\
\hline \multicolumn{7}{|c|}{ Terminal Preclassic } \\
\hline Dogs (14) & -1.3 & 2.0 & -6.3 to 1.6 & -5.8 & 0.7 & -7.0 to -4.6 \\
\hline Gophers (5) & -8.7 & 4.5 & -12.4 to -1.3 & -6.3 & 1.3 & -7.9 to -4.9 \\
\hline \multicolumn{7}{|l|}{ Early Classic } \\
\hline Deer (2) & -13.6 & 0.2 & -13.8 to -13.5 & -5.2 & 1.8 & -6.5 to -3.9 \\
\hline Dogs (2) & 0 & 0.1 & -0.1 to 0.1 & -6.2 & 0.5 & -6.6 to -5.8 \\
\hline \multicolumn{7}{|l|}{ Mixed Classic } \\
\hline Dogs (4) & -1.6 & 3.4 & -6.6 to 0.6 & -6.1 & 0.8 & -6.9 to -5.0 \\
\hline Gophers (1) & -9.5 & - & - & -7.3 & - & - \\
\hline \multicolumn{7}{|l|}{ Total } \\
\hline Deer (2) & -13.6 & 0.2 & -13.8 to -13.5 & -5.2 & 1.8 & -6.5 to -3.9 \\
\hline Dogs (23) & -1.5 & 2.1 & -6.6 to 1.6 & -5.9 & 0.7 & -7.0 to -4.6 \\
\hline Gophers (9) & -8.4 & 3.6 & -12.4 to -1.3 & -6.5 & 1.4 & -8.9 to -4.8 \\
\hline
\end{tabular}


in the Early Classic deposits of the Palangana. Considering that no other deer bones were found nearby, it may have been part of an adornment or other artifact brought to Kaminaljuyu from elsewhere. Since the deposit was not a special cache or dedicatory offering like other deposits in the same structure, another possibility is that it had been part of secondary midden material redeposited from elsewhere, likely from the vicinity around the Palangana structure.

The non-local animals, including the gophers that will be examined more closely in the next section, comprise almost $20 \%$ of the animal teeth tested in this study. The majority of these came from special deposits, likely as offerings. Although most animals recovered from Kaminaljuyu came from special deposits, where preservation is better than in domestic deposits, other sourcing studies in the Maya region have noted that non-local terrestrial mammals are rare (e.g., Rand et al. 2020, 2021; Sharpe et al. 2018; Thornton 2011; Thornton et al. 2016). When they are encountered, they are usually found in special contexts (Sharpe et al. 2018; Thornton 2011). Unlike other regions of the world where the long-distance exchange of mammals contributed to subsistence activities and marketplace economies, mammals may have been primarily transported for ceremonial or ritual purposes among the Prehispanic Maya. There is evidence that marine fish were exchanged for subsistence purposes in the Yucatan (Jiménez-Cano and Masson 2016; Masson and Peraza Lope 2008), although evidence for marine fish exchange into Belize and the central Maya lowlands is rare and usually comprises brightly colored species like parrotfish that may have been used for special functions (Boileau and Stanchly 2020; Brady et al. 2019). If ceremonial activities drove the need to acquire non-local species, which has been demonstrated previously with marine shells (see Sharpe 2019 for a review), this would indicate that rituals reinforced communication and the exchange of resources as well as ideas among the different parts of the Maya area.

\section{Closer examination of potentially non-local gophers}

The unusually high ${ }^{87} \mathrm{Sr} /{ }^{86} \mathrm{Sr}$ values of two pocket gophers in the Mound E-III-3 dedicatory offering were an unexpected finding (Fig. 4). There was a minimum of three gophers in the assemblage, determined by the number of repeating cranial elements and maxillary dentition. At least one of the gophers was partly burned, and limb bones of at least two individuals were recovered. Since many of the other animal bones in the deposit had been burned, including a large quantity of organic material that contained carbonized seeds, the gophers were likely part of the deposit and not later intrusive additions who had burrowed inside. There is currently no evidence for gopher exchange in the Maya region; in fact, gophers and other small rodents are often assumed to be "local" to the site where they are recovered. Rodents, (especially mice) are frequently used for creating local isotopic baselines globally for this reason (Conlee et al. 2009; Kootker et al. 2016; Price et al. 2002; Sharpe et al. 2021). Only recently has the potential for non-local small animals been raised, with the identification of a possibly non-local armadillo (Dasypus novemcinctus) and agouti (Dasyprocta punctata) using sulfur isotopes from two sites around the Chetumal Bay (Rand et al. 2021).

Since the gophers had been found near the marine fish and shells, and marine fish are expected to have the modern marine ${ }^{87} \mathrm{Sr} /{ }^{86} \mathrm{Sr}$ value $(\sim 0.70917)$, we decided to test the possibility that the gopher enamel of the two higher-strontium samples may have diagenetically exchanged strontium from their proximity near the fish. Although rodent enamel is softer than that of most mammals (von Koenigswald 1985), it is denser than dentin and bone. Thus, the bone and dentin from these same specimens should also have elevated ${ }^{87} \mathrm{Sr} /{ }^{86} \mathrm{Sr}$ values if the specimens were absorbing strontium from the fish. We tested the dentin of all three incisors and bone of the cranium of one individual (incisor EN-06). The results showed that dentin ${ }^{87} \mathrm{Sr} /{ }^{86} \mathrm{Sr}$ from the two possible non-local gophers were also elevated above
Fig. 4 Hispid pocket gopher (Orthogeomys hispidus) mandible from the Mound E-III-3 base deposit (far left) compared with a modern mandible of the same species. Photo of a live pocket gopher taken from Chankom, Mexico (courtesy of Angel Castillo Cime, CC BY-NC)

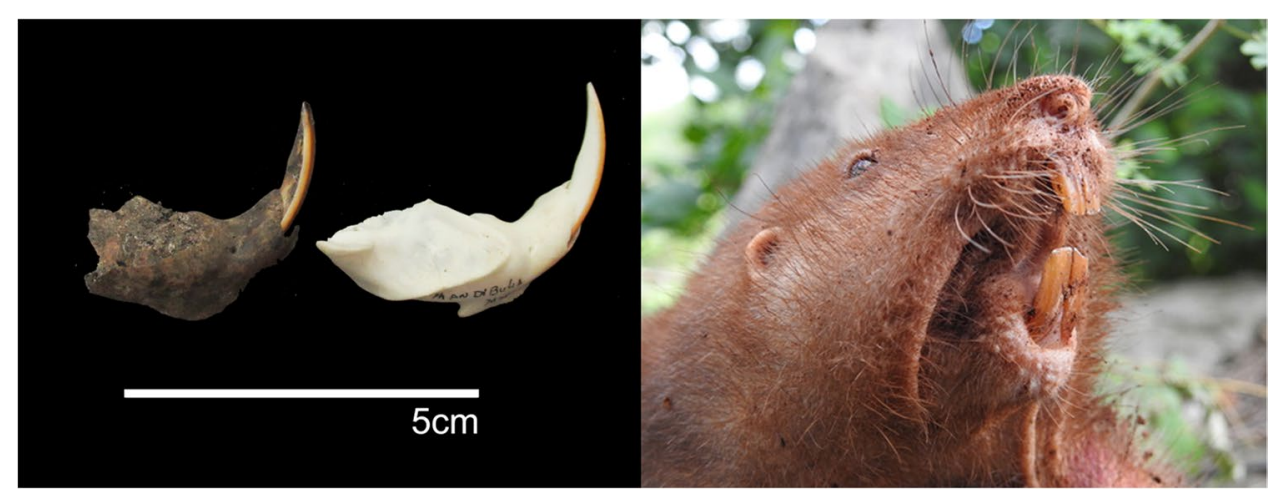


Table $3{ }^{87} \mathrm{Sr} /{ }^{86} \mathrm{Sr}$ of dentin and bone from the three gophers in the Mound E-III-3 base deposit

\begin{tabular}{lllll}
\hline Specimen number & Material & ${ }^{87} \mathrm{Sr} /{ }^{86} \mathrm{Sr}$ & $2 \sigma$ Error & Enamel correlate \\
\hline BCL-5464 & Dentin & 0.705706 & 0.000026 & $\mathrm{EN}-04$ \\
BCL-5465 & Dentin & 0.704154 & 0.000034 & $\mathrm{EN}-05$ \\
BCL-5466 & Dentin & 0.705110 & 0.000028 & $\mathrm{EN}-06$ \\
BCL-5463 & Bone & 0.704746 & 0.000014 & $\mathrm{EN}-06$
\end{tabular}

the local baseline, but not as high as the enamel (Table 3). The bone ${ }^{87} \mathrm{Sr} /{ }^{86} \mathrm{Sr}$ was 0.70475 , which is within the local range for Kaminaljuyu. This means that post-deposition contact with the marine fish is not likely the cause of the elevated ${ }^{87} \mathrm{Sr} /{ }^{86} \mathrm{Sr}$ in the enamel. The lower ${ }^{87} \mathrm{Sr} /{ }^{86} \mathrm{Sr}$ values of the dentin and bone would be expected due to diagenetic alteration caused by the surrounding volcanic matrix, which is why bone and dentin are typically not used for ${ }^{87} \mathrm{Sr} /{ }^{86} \mathrm{Sr}$ sourcing studies (Budd et al. 2000; Hoppe et al. 2003). Given the scarcity of calcium in the volcanic soils at Kaminaljuyu, we anticipate that leaching of $\mathrm{CaCO}_{3}$ out of the skeletal matrix characterizes the process of skeletal decay during burial, rather than recrystallization of diagenetic carbonates.

We are therefore left with the possibility that the two gophers were not from Kaminaljuyu or the nearby area. One gopher had a ${ }^{87} \mathrm{Sr} /{ }^{86} \mathrm{Sr}$ value of 0.70754 , and the other a value of 0.70598 . Since gopher enamel is softer than that of other mammals, it is possible that some degree of diagenesis had occurred and altered the original values, so they may have been higher originally. Oxygen isotope values of the two gophers are similar to those of the other gophers in the study (Table 1), although one (EN-06) had the highest $\delta^{18} \mathrm{O}_{\text {en }}$ value of any gopher tested $(-4.8 \%$ ). We cannot be certain where the two gophers originated, although their isotopic values match the southern lowlands in the case of the higher strontium value, and the region of metamorphic geology around the Motagua Valley for the gopher with the lower value (Hodell et al. 2004).

The non-local dog, marine fish, and shells indicate there were a number of exotic items intentionally incorporated into this dedicatory offering, and the gophers may be no exception. Examination of the role of pocket gophers in Classic period Maya art has led Stone et al. (2011:81-82) to suggest they may have been used as pets, since they are depicted in the arms of individuals or seated nearby. While gopher bones are occasionally found at Maya sites (e.g., Boileau and Stanchly 2020; Sharpe et al. 2020; Wing 1981), the rarity of their remains indicates they were not a common staple. Gophers are hunted today in the Maya area such as the Quintana Roo region where snare traps are placed near burrows (Hovey and Rissolo 1999). They have also been reportedly sold in markets in Chiapas (Barragán et al. 2007). The human-mediated translocation of rodents, including guinea pigs (Cavia porcellus) and hutia (Geocapromys ingrahami and Isolobodon portoricensis), has been well documented within the faunal records of the Caribbean islands (e.g., Giovas et al. 2012; LeFebvre and deFrance 2014; LeFebvre et al. 2019a). The case of the two non-local gophers interred in the Mound E-III-3 base deposit suggests this diminutive rodent may have had a larger role in Maya rituals than previously believed. It also serves as a warning against the assumption that rodents and other small mammals were moved infrequently by humans in the past, supporting similar evidence found recently by Rand et al. (2021) concerning armadillos and agoutis. Whether the long-distance movement of rodents was a frequent activity across the Maya region, or done primarily for special, ceremonial purposes, is a question that warrants further investigation.

\section{Comparison of human and animal mobility at Kaminaljuyu}

Prior data from 42 humans at Kaminaljuyu found that ten teeth, or eight individuals (since some teeth came from the same person), had ${ }^{87} \mathrm{Sr} /{ }^{86} \mathrm{Sr}$ values exceeding 0.7050 (Valdés and Wright 2004; Wright et al. 2010). These individuals generally had elevated $\delta^{18} \mathrm{O}_{\mathrm{en}}$ as well (mean $-3.0 \%$, with two exceeding $-2.0 \%$ o). Although human teeth were tested for strontium from the Late Preclassic through Late Classic periods, all isotopically elevated samples came from Early Classic burials. Seven of these individuals came from the Mound A and B tombs, and of these, six were children or adolescents possibly buried to accompany the central adult interment. Some may have been secondary deposits, pushed aside in the tombs at a time of reuse. Preservation of the children and adolescent skeletons was often poor and resulted in incomplete recovery of skeletal remains, but in a few cases, it was clear that only isolated skulls had been deposited. The skulls of four children were not local to Kaminaljuyu, including one with a ${ }^{87} \mathrm{Sr} /{ }^{86} \mathrm{Sr}$ value matching the Maya Mountains region of Belize or another area with metamorphic bedrock exhibiting a similar value (0.71050). The only tomb examined from Mound B (B-IV) included a non-local adult $\left({ }^{87} \mathrm{Sr} /{ }^{86} \mathrm{Sr}=0.70694\right)$ who may have been one of the central occupants. The only non-local individual found outside Mounds A and B was recovered from the Palangana and appears to have been an adult male $\left({ }^{87} \mathrm{Sr} /{ }^{86} \mathrm{Sr}=0.70600\right)$.

With the exception of the adult from Tomb B-IV and the Palangana burial, the other five individuals had ${ }^{87} \mathrm{Sr} /{ }^{86} \mathrm{Sr}$ and $\delta^{18} \mathrm{O}_{\mathrm{en}}$ values that formed a distinct cluster removed from the other humans and animals $\left({ }^{87} \mathrm{Sr} /{ }^{86} \mathrm{Sr}=0.7050-0.7060\right.$, $\delta^{18} \mathrm{O}_{\mathrm{en}}>-3.5 \%$ ). This suggests these individuals came from the same general location, which did not match the source of the non-local animals. An area to the east of Kaminaljuyu would seem mostly likely based on these values, 
perhaps somewhere on the eastern slopes of the highlands or the Motagua Valley. Interestingly, no human ${ }^{87} \mathrm{Sr} /{ }^{86} \mathrm{Sr}$ values matched the southern Maya lowlands, despite an abundance of artifactual and artistic evidence supporting continuous interaction with the region since the Middle Preclassic period (Arroyo et al. 2020; Inomata et al. 2014; Kaplan 2011).

The majority of animals match the human ${ }^{87} \mathrm{Sr} /{ }^{86} \mathrm{Sr}$ values ( 0.7040-0.7050). Compared to the humans, the generally lower $\delta^{18} \mathrm{O}_{\mathrm{en}}$ exhibited among all three animal species in this study is likely the result of drinking and metabolic differences between these species and humans (Table 2). Gophers obtain much of their water from vegetation, which may be why their $\delta^{18} \mathrm{O}_{\mathrm{en}}$ values are lower than those of humans. The $\operatorname{dog} \delta^{18} \mathrm{O}_{\mathrm{en}}$ range overlaps more with the humans, but is also lower on average. This may be due to a metabolic or dietary difference between dogs and humans.

Although all humans with elevated ${ }^{87} \mathrm{Sr} /{ }^{86} \mathrm{Sr}$ date to the Early Classic period, only one potentially non-local animal was deposited during this time. This was the deer mandible recovered in the Palangana, with a strontium value $(0.70790)$ that did not match any of the human ${ }^{87} \mathrm{Sr} /{ }^{86} \mathrm{Sr}$ values since it was comparable with the southern lowlands. The other animals with elevated ${ }^{87} \mathrm{Sr} /{ }^{86} \mathrm{Sr}$ came from the Late Preclassic Mound E-III-3 dedication deposit and the Palangana's Terminal Preclassic deposits. There is little correlation in the ${ }^{87} \mathrm{Sr} /{ }^{86} \mathrm{Sr}$ and $\delta^{18} \mathrm{O}_{\text {en }}$ values among either the fauna or with the humans; most appear to have come from the foothills of central Guatemala or perhaps the Motagua Valley. One of the dogs (EN-02) may have come from the Motagua or Copan Valleys, based on similar strontium and oxygen values (0.70692 and $-5.2 \%$; Price et al. 2010). A second dog's strontium and oxygen values (EN-18, 0.70654 and $-7.0 \%$ ) more closely align with an area of the Pacific coast to the north in Mexico, such as the Soconusco region (Renson et al. 2019). Ultimately, until more data is available, we can only conclude that the movements of animals and humans to Kaminaljuyu over time were highly variable. Non-local humans and animals appear to have been frequently interred in special deposits, such as tombs and dedicatory offerings, but their locations of origin varied widely.

\section{Comparing human and animal diet: enamel $\delta^{13} \mathrm{C}$}

Enamel carbon isotope values $\left(\delta^{13} \mathrm{C}_{\mathrm{en}}\right)$ reflect the diet of animals, including humans, while enamel is still forming. A previous study at Kaminaljuyu by Wright and Schwarcz (1998) comparing the $\delta^{13} \mathrm{C}_{\mathrm{en}}$ of multiple teeth within the same individual found that the $\delta^{13} \mathrm{C}_{\mathrm{en}}$ of the first molars of humans was generally lower than permanent premolars and second and third molars, which have later enamel formation. The latter contain the $\delta^{13} \mathrm{C}_{\mathrm{en}}$ values after the introduction of solid foods into the diet, which largely consisted of maize.

Figure 5 compares the $\delta^{13} \mathrm{C}_{\text {en }}$ values of local animals along with humans, excluding the first molar. Human and dog dietary $\delta^{13} \mathrm{C}_{\mathrm{en}}$ are most similar during the Late/Terminal Preclassic period, but dog diets show elevated $\delta^{13} \mathrm{C}_{\mathrm{en}}$ in later periods. This may indicate that maize was more prevalent in dog diets, on average, compared to humans during the Early and Late Classic periods. Nevertheless, dog dietary $\delta^{13} \mathrm{C}_{\mathrm{en}}$ values also exhibit more variation in the Late/Terminal Preclassic and Late Classic periods compared to humans, indicating that maize consumption was variable within the species. The diversity in dog diets compared to humans suggests there was no standard dog "diet" at the site, and dogs were likely fed a variety of different foods. Dog dietary diversity has been identified at other Maya sites as well, such as Ceibal (Sharpe et al. 2018), Colha (White et al. 2001), and Lagartero (White et al. 2004). It may be related to the differential rearing of certain breeds or morphotypes, a question that needs to be examined more closely at Kaminaljuyu and throughout the Maya area.

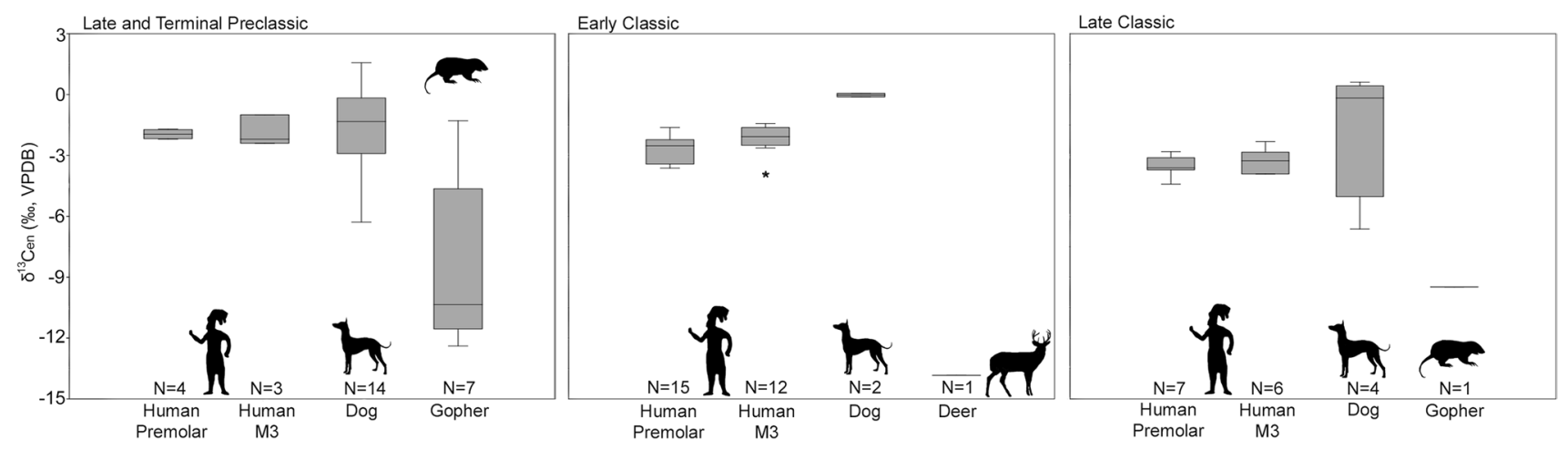

Fig. 5 Comparison of human and animal enamel $\delta^{13} \mathrm{C}$ at Kaminaljuyu through time. Box plot whiskers display distance 1.5 times the interquartile range. Non-local humans and animals are excluded. Late
Classic phase includes some animals from mixed Classic (Early/Late) deposits around the Acropolis 
During the Early Classic period, all dogs appear to have been consuming a greater proportion of maize in their diets than humans (mean $\operatorname{dog} \delta^{13} \mathrm{C}_{\mathrm{en}}=0 \%$, mean human $\delta^{13} \mathrm{C}_{\mathrm{en}}=-2.4 \%$ excluding first molars). While dogs from other periods come from varied deposits, the two Early Classic specimens came from the same excavation unit in the Palangana. While they are two different individuals, the teeth were found with a few other scattered dog bones in the construction fill as a secondary deposit. A greater sample size of dogs from this period may reveal that Early Classic dogs had more variation in the diet, comparable to other periods.

Deer and gophers consumed more $\mathrm{C}_{3}$ plants than dogs. Both the local and non-local deer had the lowest $\delta^{13} \mathrm{C}_{\text {en }}$ values of any animals ( $-13.8 \%$ and $-13.5 \%$, respectively), suggesting they were primarily consuming $\mathrm{C}_{3}$ plants. Most of the gophers had low or intermediate $\delta^{13} C_{\text {en }}$ values between the deer and the humans/dogs, although one gopher from the Palangana had consumed $\mathrm{C}_{4}$ plants at a level comparable with the dogs $(-1.3 \%)$. Gophers are known to eat maize in addition to other grasses, so this is not unexpected (Whisson and Villa-C 1996). It may have come from an agricultural zone or cleared field nearby. Alternatively, it is possible that this particular gopher was kept in captivity and fed a diet rich in maize, similar to the dogs. Examples of elevated $\delta^{13} \mathrm{C}_{\mathrm{en}}$ in Prehispanic rodents that may have been maintained in captivity have been identified among Bahamian hutia (Geocapromys ingrahami) in the Caribbean (LeFebvre et al. 2019b) and guinea pigs (Cavia porcellus) in the Andes (Finucane et al. 2006).

Interestingly, place of origin does not appear to have shaped animal diets. The $\delta^{13} \mathrm{C}_{\mathrm{en}}$ of local and non-local dogs from the Preclassic overlap (mean $\delta^{13} \mathrm{C}_{\mathrm{en}}$ is $-1.6 \%$ in both cases, with non-local dog values falling within the local dog range). Both deer have near-identical $\delta^{13} \mathrm{C}_{\mathrm{en}}$, despite one deer possibly originating in the humid lowlands, a region with distinctly different vegetation than the highlands. The $\delta^{13} \mathrm{C}_{\mathrm{en}}$ of the two non-local gophers are dissimilar ( $-7.5 \%$ o and $-10.7 \%$ ) , as are their strontium and oxygen values. Since these values overlap with those of the other gophers at Kaminaljuyu, we cannot use diet to argue that these two gophers were treated differently or kept in captivity (i.e., as pets or to be raised as special offerings with unique diets). Nevertheless, the elevated $\delta^{13} \mathrm{C}_{\mathrm{en}}$ compared to the deer samples suggests that these two gophers may have had some maize in their diet. Their diets may have been influenced by humans, either intentionally (kept in captivity and fed some maize) or unintentionally (consumed some maize from agricultural fields). Both gophers may have lived in closed proximity to human settlements.

Although there have been a number of studies in the Maya area of animal diets using $\delta^{13} \mathrm{C}$ of bone collagen, very few studies have used dental enamel. This is surprising considering that it is now frequently used to examine paleodiet in extinct fossil species (e.g., Cerling and Sharp 1996; Cerling et al. 1997; Feranec and MacFadden 2000; Lee-Thorp et al. 2010). Three exceptions include a study done of multiple animals at Ceibal (Sharpe et al. 2018), a study of felids and one deer at Copan (Sugiyama et al. 2018), and a deer and peccary at Cuello (van der Merwe et al. 2000). The dog and white-tailed deer carbon isotope data from these studies is compared with that of Kaminaljuyu in Fig. 6. The dogs from Ceibal have lower $\delta^{13} \mathrm{C}_{\mathrm{en}}$ values (mean $=-5.7 \%$ o) than the humans and dogs from Kaminaljuyu (mean $=-2.6 \%$ o and $-1.5 \%$, respectively). Interestingly, the deer from all three studies are comparable with the deer from Kaminaljuyu, with a range of only $1.3 \%$ across all four sites $(-13.9$ to $-12.6 \%$ ). This represents a remarkable degree of consistency in deer diets across the Maya area, independent of regional vegetation differences. It also underscores the role maize played in domestic omnivore diets in the Maya region.

\section{Conclusions}

By examining the isotopic composition of animal teeth at Kaminaljuyu, we have found that the results both support and expand on what we know regarding the movements and diets of humans at the site. The majority of the animals appear to have originated from in or nearby Kaminaljuyu. This supports similar isotopic analysis on the human dental enamel, which found that most humans interred at the site were likely from the highlands. The few distinctly nonlocal animal specimens appear to have come from diverse

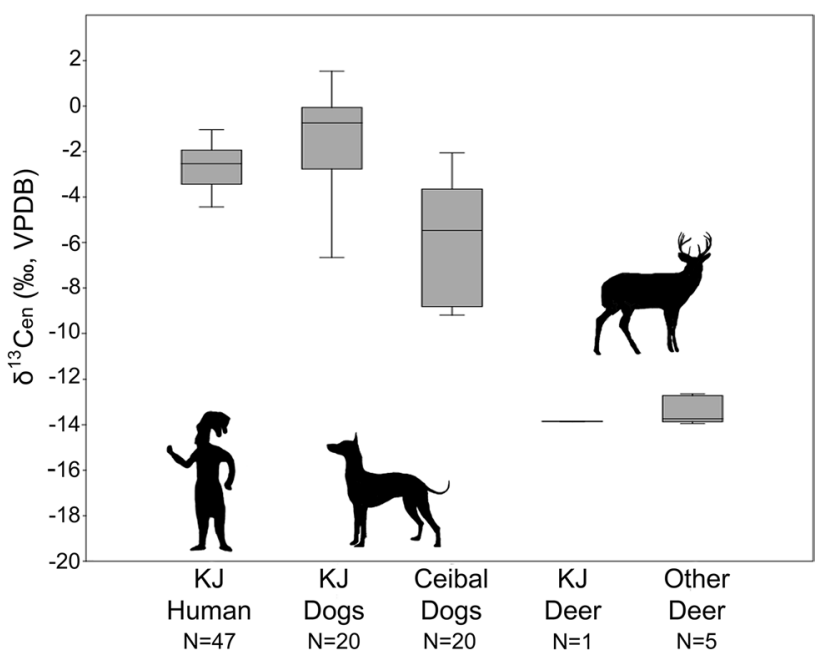

Fig. 6 Comparison of local Kaminaljuyu human (no first molar) and animal enamel $\delta^{13} \mathrm{C}$ with values reported from dogs and white-tailed deer at other sites. Ceibal data from Sharpe et al. (2018; excludes two dogs that had been reported as non-local), Copan deer data from Sugiyama et al. (2018), and Cuello deer data from van der Merwe et al. (2000) 
locations across the Maya region. These locations do not correspond with the isotopic values of the non-local human individuals, nor does the presence of non-local animals and individuals correlate in time. The results also suggest that oxygen isotope values in animals may vary differently in relation to those of humans due to biological and behavioral factors, as was previously noted in other investigations using modern animals. While oxygen values may support interpretations of mobility based on strontium ratios, the latter may be more precise in sourcing studies. Enamel carbon isotopes, interestingly, reveal remarkable consistency within species across the Maya area. While there is more variability exhibited in dog diets than deer, it would appear that most dogs in the Maya area were consuming maize during both Preclassic and Classic periods.

The discrepancy between locating place of origin in the isotope values of non-local human and animal individuals supports the view long held by archaeologists that Kaminaljuyu played an important role as an exchange hub in the Maya region. There is already substantial artifactual and architectural evidence attesting to Kaminaljuyu's political and, likely, trade connections from Copan in Honduras to Teotihuacan in central Mexico. Wright et al. (2010) identified non-local individuals, some possibly captives or trophy skulls in tombs, dating exclusively to the Early Classic period. The non-local animals reported in the present study indicate long-distance exchange with other regions occurred during the Preclassic period as well. We were limited to examining three animal species due to the poor preservation of faunal remains, but it would appear the ancient Maya exchanged all three across the landscape. This includes the pocket gophers, a species typically assumed to be local at most sites when encountered. This discovery opens the possibility to the exchange of other rodents in the Maya area.

Much like the non-local human individuals identified at the site, the majority of the non-local animals was found in special contexts, mainly as dedicatory offerings. Although this is partly due to sampling bias favoring monumental architecture that contain special offerings, there is still relatively little evidence in the Maya region for the long-distance exchange of mammals for purposes other than rituals. There remains much work to be done on this matter, since a better understanding of the role of animals in Prehispanic exchange systems will enhance our understanding of Maya society as a whole.

Supplementary Information The online version contains supplementary material available at https://doi.org/10.1007/s12520-021-01498-8.

Acknowledgements The authors would like to thank the many researchers and excavation teams who have worked at Kaminaljuyu for providing the materials and information used in this study. We thank Alexandre Tokovinine for his advice on gophers in Maya art, Jason Curtis for assisting with the light stable isotope analysis, and
John Krigbaum for assisting in the analysis of the gopher bone and dentin strontium. We also thank the two anonymous reviewers for their suggested improvements on the original manuscript. Funding for this work was provided by the Alphawood Foundation and the Smithsonian Tropical Research Institute.

Author contribution AES conceived and conducted the faunal and isotope analysis and wrote the manuscript; BA and GA provided samples, contextual information, and assisted with writing and interpretations; LEW provided data and information from the prior human isotope study and assisted with writing and interpretations; GK supervised isotope analyses and assisted with data interpretation and writing; JE, ES, and EZ assisted with the analyses and interpretations. All authors read and approved the final manuscript.

Funding This study was funded by a grant from the Alphawood Foundation to Bárbara Arroyo and the Proyecto Zona Arqueológica Kaminaljuyu to conduct excavations at Kaminaljuyu, Guatemala, and by research funds provided to Ashley Sharpe from the Smithsonian Tropical Research Institute to conduct isotope analyses.

Availability of data and material All original data is provided in the manuscript and supplementary file.

Code availability Not applicable.

\section{Declarations}

Ethics approval This research was conducted with the following permits: D.A.J.-446-2017 from the Instituto de Antropología e Historia in Guatemala, and Resolución $\mathrm{N}^{\circ} 117-17$ and $\mathrm{N}^{\circ} 110-19$ from the Instituto Nacional de Cultura in Panama.

Consent to participate Not applicable.

Consent for publication Not applicable.

Conflict of interest/Competing interests The authors declare no competing interests.

Open Access This article is licensed under a Creative Commons Attribution 4.0 International License, which permits use, sharing, adaptation, distribution and reproduction in any medium or format, as long as you give appropriate credit to the original author(s) and the source, provide a link to the Creative Commons licence, and indicate if changes were made. The images or other third party material in this article are included in the article's Creative Commons licence, unless indicated otherwise in a credit line to the material. If material is not included in the article's Creative Commons licence and your intended use is not permitted by statutory regulation or exceeds the permitted use, you will need to obtain permission directly from the copyright holder. To view a copy of this licence, visit http://creativecommons.org/licenses/by/4.0/.

\section{References}

Ajú Álvarez GB (2017) La Palangana, Kaminaljuyu: su integración a la geografía sagrada en el Preclásico y Clásico. Thesis, Universidad de San Carlos de Guatemala

Ambrose SH, Norr L (1993) Experimental evidence for the relationship of the carbon isotope ratios of whole diet and dietary protein to 
those of bone collagen and carbonate. In: Lambert JB, Grupe G (eds) Prehistoric human bone: archaeology at the molecular level. Springer-Verlag, Berlin, pp 1-37. https://doi.org/10.1007/ 978-3-662-02894-0_1

Arroyo B, Inomata T, Ajú G, Estrada J, Nasu H, Aoyama K (2020) Refining Kaminaljuyu chronology: new radiocarbon dates, Bayesian analysis, and ceramics studies. Lat Am Antiq 31:477497. https://doi.org/10.1017/laq.2020.49

Barragán F, Retana OG, Naranjo EJ (2007) The rodent trade of Tzeltal Indians of Oxchuc, Chiapas, Mexico. Hum Ecol 35:769-773. https://doi.org/10.1007/s10745-007-9116-7

Bentley RA (2006) Strontium isotopes from the earth to the archaeological skeleton: a review. J Archaeol Method Theory 13:135187. https://doi.org/10.1007/s10816-006-9009-x

Boileau A, Stanchly N (2020) Middle Preclassic faunal utilisation at Pacbitun, Belize: evidence for social differentiation, exchange, and craft specialisation. In: Powis TG, Skaggs S, Micheletti G (eds) An archaeological reconstruction of ancient Maya life at Pacbitun, Belize. BAR Publishing, Oxford, pp 41-54

Brady JE, Saldaña M, Orozco J (2019) Finding drama in bones: looking beyond identification in ritual faunal. J Anthropol Archaeol 7:39-48. https://doi.org/10.15640/jaa.v7n1a4

Braswell GE (2003) Understanding Early Classic interaction between Kaminaljuyu and Central Mexico. In: Braswell GE (ed) The Maya and Teotihuacan: reinterpreting Early Classic interaction. University of Texas Press, Austin, pp 105-142

Brenner M, Hodell DA, Curtis JH, Rosenmeier MF, Anselmetti FS, Ariztegui D (2003) Paleolimnological approaches for inferring past climate change in the Maya region: recent advances and methodological limitations. In: Gomez-Pompa A, Fedick SL (eds) The lowland Maya area: three millennia at the humanwildland interface. Haworth Press, New York, pp 45-76

Bryant DJ, Froelich PN (1995) A model of oxygen isotope fractionation in body water of large mammals. Geochim Cosmochim Acta 59:4523-4537. https://doi.org/10.1016/0016-7037(95)00250-4

Budd P, Montgomery J, Barreiro B, Thomas RG (2000) Differential diagenesis of strontium in archaeological human dental tissues. Applied Geochem 15:687-694. https://doi.org/10.1016/S08832927(99)00069-4

Cerling TE, Sharp ZD (1996) Stable carbon and oxygen isotope analysis of fossil tooth enamel using laser ablation. Palaeogeo Palaeoclim Palaeoecol 126:173-186. https://doi.org/10.1016/ S0031-0182(96)00078-8

Cerling TE, Harris JM, MacFadden BJ, Leakey MG, Quade J, Eisenmann V, Ehleringer JR (1997) Global vegetation change through the Miocene/Pliocene boundary. Nature 389:153-158. https:// doi.org/10.1038/38229

Conlee CA, Buzon MR, Gutierrez AN, Simonetti A, Creaser RA (2009) Identifying foreigners versus locals in a burial population from Nasca, Peru: an investigation using strontium isotope analysis. J Archaeol Sci 36:2755-2764. https://doi.org/10.1016/j. jas.2009.08.016

Cormie AB, Schwarcz HP (1994) Stable isotopes of nitrogen and carbon of North American white-tailed deer and implications for paleodietary and other food web studies. Palaeogeo Palaeoclim Palaeoecol 107:227-241. https://doi.org/10.1016/0031-0182(94) 90096-5

Darr RL, Hewitt DG (2008) Stable isotope trophic shifts in white-tailed deer. J Wildlife Manage 72:1525-1531. https://doi.org/10.2193/ 2006-293

DeNiro MJ, Epstein S (1978) Influence of diet on the distribution of carbon isotopes in animals. Geochim Cosmochim Acta 42:495506. https://doi.org/10.1016/0016-7037(78)90199-0
Emery KF, Wright LE, Schwarcz H (2000) Isotopic analysis of ancient deer bone: biotic stability in collapse period Maya land-use. J Archaeol Sci 27:537-550. https://doi.org/10.1006/jasc.1999. 0491

Emery KF, Thornton EK (2008) A regional perspective on biotic change during the Classic Maya occupation using zooarchaeological isotopic chemistry. Quat Int 191:131-143. https://doi.org/ 10.1016/j.quaint.2007.11.015

Estrada de la Cerda J (2017) Caminos ancestrales: las rutas de Kaminaljuyu durante el Preclásico Tardío. Thesis, Universidad de San Carlos

Feranec RS, MacFadden BJ (2000) Evolution of the grazing niche in Pleistocene mammals from Florida: evidence from stable isotopes. Palaeogeo Palaeoclim Palaeoecol 162:155-169. https:// doi.org/10.1016/S0031-0182(00)00110-3

Finucane B, Maita Agurto P, Isbell WH (2006) Human and animal diet at Conchopata, Peru: stable isotope evidence for maize agriculture and animal management practices during the Middle Horizon. J Archaeol Sci 33:1766-1776. https://doi.org/10. 1016/j.jas.2006.03.012

Freiwald C, Pugh T (2017) The origins of early Colonial cows at San Bernabé, Guatemala: strontium isotope values at an early Spanish mission in the Petén lakes region of northern Guatemala. Environ Archaeol 23:80-96. https://doi.org/10.1080/14614103. 2017.1297012

Freiwald C, Miller Wolf KA, Pugh T, Rand AJ, Fullagar PD (2020) Early colonialism and population movement at the Mission San Bernabé, Guatemala. Anc Mesoam 31:543-553. https:// doi.org/10.1017/S0956536120000218

Gerry JP, Krueger HW (1997) Regional diversity in Classic Maya diets. In: Whittington SL, Reed DM (eds) Bones of the Maya: studies of ancient skeletons. Smithsonian Institution Press, Washington, D.C., pp 196-207

Giovas CM, LeFebvre MJ, Fitzpatrick SM (2012) New records for prehistoric introduction of Neotropical mammals to the West Indies: evidence from Carriacou, Lesser Antilles. J Biogeogr 39:476-487. https://doi.org/10.1111/j.1365-2699.2011. 02630.x

Guiry EJ (2012) Dogs as analogs in stable isotope-based human paleodietary reconstructions: a review and considerations for future use. J Archaeol Method Theory 19:351-376. https://doi. org/10.1007/s10816-011-9118-Z

Hedges REM, Clement JG, Thomas CDL, O'Connell TC (2007) Collagen turnover in the adult femoral mid-shaft: modeled from anthropogenic radiocarbon tracer measurements. Am J Phys Anthropol 133:808-816. https://doi.org/10.1002/ajpa.20598

Hodell DA, Quinn RL, Brenner M, Kamenov G (2004) Spatial variation of strontium isotopes $\left({ }^{87} \mathrm{Sr} /{ }^{86} \mathrm{Sr}\right)$ in the Maya region: a tool for tracking ancient human migration. J Archaeol Sci 31:585601. https://doi.org/10.1016/j.jas.2003.10.009

Hoppe KA, Koch PL, Furutani TT (2003) Assessing the preservation of biogenic strontium in fossil bones and tooth enamel. Int $\mathrm{J}$ Osteoarchaeol 13:20-28. https://doi.org/10.1002/oa.663

Hovey K, Rissolo D (1999) The process and sociocultural significance of gopher trapping in a modern Yucatec Maya community. J Ethnobiol 19:261-276

Inomata T, Ortiz R, Arroyo B, Robinson EJ (2014) Chronological revision of Preclassic Kaminaljuyú, Guatemala: implications for social processes in the southern Maya area. Lat Am Antiq 25:377-408. https://doi.org/10.7183/1045-6635.25.4.377

Islebe GA, Velázquez A, Cleef AM (1995) High elevation coniferous vegetation of Guatemala. Vegetatio 116:7-23. https://doi.org/10. 1007/BF00045273 
Jernvall J, Thesleff I (2012) Tooth shape formation and tooth renewal: evolving with the same signals. Development 139:3487-3497. https://doi.org/10.1242/dev.085084

Jiménez-Cano NG, Masson MA (2016) Estimation of fish size from archaeological bones of hardhead catfishes (Ariopsis felis): assessing pre-Hispanic fish acquisition of two Mayan sites. J Archaeol Sci Rep 8:116-120. https://doi.org/10.1016/j.jasrep. 2016.05.063

Kamenov GD, Lofaro EM, Goad G, Krigbaum J (2018) Trace elements in modern and archaeological human teeth: implications for human metal exposure and enamel diagenetic changes. $\mathbf{J}$ Archaeol Sci 99:27-34. https://doi.org/10.1016/j.jas.2018.09.002

Kaplan J (2011) Miraflores Kaminaljuyu: corpse and corpus delicti. In: Love M, Kaplan J (eds) The southern Maya in the Late Preclassic: the rise and fall of an early Mesoamerican civilization. University Press of Colorado, Boulder, pp 237-286

Kays R, Feranec RS (2011) Using stable carbon isotopes to distinguish wild from captive wolves. Northeast Natural 18:253-264

Kidder AV (1945) Excavations at Kaminaljuyu, Guatemala. Am Antiq 11:65-75. https://doi.org/10.2307/275651

Kidder AV, Jennings JD, Shook EM (1946) Excavations at Kaminaljuyu, Guatemala. Carnegie Institute of Washington, Washington

Kootker LM, van Lanen RJ, Kars H, Davies GR (2016) Strontium isoscapes in the Netherlands. spatial variations in ${ }^{87} \mathrm{Sr} /{ }^{86} \mathrm{Sr}$ as a proxy for palaeomobility. J Archaeol Sci Rep 6:1-13. https://doi. org/10.1016/j.jasrep.2016.01.015

Lachniet MS, Patterson WP (2009) Oxygen isotope values of precipitation and surface waters in northern Central America (Belize and Guatemala) are dominated by temperature and amount effects. Earth Planet Sci Let 284:435-446. https://doi.org/10.1016/j.epsl. 2009.05.010

Lee-Thorp JA, Sponheimer M, Passey BH, de Ruiter DJ, Cerling TE (2010) Stable isotopes in fossil hominin tooth enamel suggest a fundamental dietary shift in the Pliocene. Philos Trans R Soc B Biol Sci 365:3389-3396. https://doi.org/10.1098/rstb.2010.0059

LeFebvre MJ, deFrance SD (2014) Guinea pigs in the Pre-Columbian West Indies. J Island Coast Archaeol 9:16-44. https://doi.org/10. 1080/15564894.2013.861545

LeFebvre MJ, DuChemin G, deFrance SD, Keegan WF, Walczesky K (2019a) Bahamian hutia (Geocapromys ingrahami) in the Lucayan Realm: Pre-Columbian exploitation and translocation. Environ Archaeol 24:115-131. https://doi.org/10.1080/14614 103.2018.1503809

LeFebvre MJ, deFrance SD, Kamenov GD, Keegan WF, Krigbaum J (2019b) The zooarchaeology and isotopic ecology of the Bahamian hutia (Geocapromys ingrahami): evidence for pre-Columbian anthropogenic management. PLoS ONE 14:e0220284. https://doi.org/10.1371/journal.pone.0220284

Masson MA, Peraza Lope C (2008) Animal use at the Postclassic Maya center of Mayapán. Quat Int 191:170-183. https://doi.org/10. 1016/j.quaint.2008.02.002

Matsubayashi J, Tayasu I (2019) Collagen turnover and isotopic records in cortical bone. J Archaeol Sci 106:37-44. https://doi.org/10. 1016/j.jas.2019.03.010

Michels JW, Sanders WT (1973) The Pennsylvania State University Kaminaljuyu Project - 1969, 1970 Seasons. Pennsylvania State University, University Park

Miller Wolf KA, Freiwald C (2018) Re-interpreting ancient Maya mobility: a strontium isotope baseline for Western Honduras. J Archaeol Sci Rep 20:799-807. https://doi.org/10.1016/j.jasrep. 2018.04.023

O'Leary MH (1981) Carbon isotope fractionation in plants. Phytochem 20:553-567. https://doi.org/10.1016/0031-9422(81)85134-5
Pederzani S, Britton K (2019) Oxygen isotopes in bioarchaeology: principles and applications, challenges and opportunities. EarthSci Rev 188:77-107. https://doi.org/10.1016/j.earscirev.2018.11. 005

Pietsch SJ, Hobson KA, Wassenaar LI, Tütken T (2011) Tracking cats: problems with placing feline carnivores on $\delta^{18} \mathrm{O}, \delta \mathrm{D}$ isoscapes. PLoS ONE 6:e24601. https://doi.org/10.1371/journal.pone. 0024601

Pin C, Bassin C (1992) Evaluation of a strontium-specific extraction chromatographic method for isotopic analysis in geological materials. Analyt Chim Acta 269:249-255. https://doi.org/10.1016/ 0003-2670(92)85409-Y

Popenoe de Hatch M (2002) New perspectives on Kaminaljuyu, Guatemala: regional interaction during the Preclassic and Classic periods. In: Love MW, Popenoe de Hatch M, Escobedo HL (eds) Incidents of archaeology in Central America and Yucatán: studies in honor of Edwin M. Shook. University Press of America, Lanham, pp 277-296

Price TD, Burton JH, Bentley RA (2002) The characterization of biologically available strontium isotope ratios for the study of prehistoric migration. Archaeom 44:117-135. https://doi.org/10. 1111/1475-4754.00047

Price TD, Burton JH, Fullagar PD, Wright LE, Buikstra JE, Tiesler Blos V (2008) Strontium isotopes and the study of human mobility in ancient Mesoamerica. Lat Am Antiq 19:167-180. https:// doi.org/10.2307/25478222

Price TD, Burton JH, Sharer RJ, Buikstra JE, Wright LE, Traxler LP, Miller KA (2010) Kings and commoners at Copan: isotopic evidence for origins and movement in the Classic Maya period. J Anthropol Archaeol 29:15-32. https://doi.org/10.1016/j.jaa.2009.10.001

Price TD, Tiesler V, Freiwald C (2019) Place of origin of the sacrificial victims in the sacred Cenote, Chichén Itzá, Mexico. Am J Phys Anthropol 170:98-115. https://doi.org/10.1002/ajpa.23879

Rand AJ, Matute V, Grimes V, Freiwald C, Źrałka J, Koszkul W (2020) Prehispanic Maya diet and mobility at Nakum, Guatemala: a multi-isotopic approach. J Archaeol Sci Rep 32:102374. https:// doi.org/10.1016/j.jasrep.2020.102374

Rand AJ, Freiwald C, Grimes V (2021) A multi-isotopic $\left(\delta^{13} \mathrm{C}, \delta^{15} \mathrm{~N}\right.$, and $\delta^{34} \mathrm{~S}$ ) faunal baseline for Maya subsistence and migration studies. J Archaeol Sci Rep 37:102977. https://doi.org/10.1016/j. jasrep.2021.102977

Renson V, Navarro-Castillo M, Cucina A, Culleton BJ, Kennett DJ, Neff H (2019) Origin and diet of inhabitants of the Pacific Coast of Southern Mexico during the Classic Period - $\mathrm{Sr}, \mathrm{C}$ and N isotopes. J Archaeol Sci Rep 27:101981. https://doi.org/10.1016/j. jasrep.2019.101981

Repussard A, Schwarcz HP, Emery KF, Thornton EK (2014) Oxygen isotopes from Maya archaeological deer remains: experiments in tracing droughts using bones. In: Iannone G (ed) The great Maya droughts in cultural context: case studies in resilience and vulnerability. University Press of Colorado, Boulder, pp 231-254. https://doi.org/10.5876/9781607322801.c011

Rogers KL, Wang Y (2002) Stable isotopes in pocket gopher teeth as evidence of a Late Matuyama climate shift in the southern Rocky Mountains. Quat Res 57:200-207. https://doi.org/10.1006/qres. 2001.2309

Scherer AK, de Carteret A, Newman S (2015) Local water resource variability and oxygen isotopic reconstructions of mobility: a case study from the Maya area. J Archaeol Sci Rep 2:666-676. https://doi.org/10.1016/j.jasrep.2014.11.006

Serech van Haute E (2018) El entorno natural y las relaciones ecológicas de Kaminaljuyu del Preclásico Tardío al Clásico Temprano, visto desde las manifestaciones de fauna entre los Montículos A-IV-1 y A-IV-2. Thesis, Universidad de San Carlos de Guatemala 
Sharpe AE (2019) The ancient shell collectors: two millennia of marine shell exchange at Ceibal, Guatemala. Anc Mesoam 30:493-516. https://doi.org/10.1017/S0956536118000366

Sharpe AE, Emery KF, Inomata T, Triadan D, Kamenov GD, Krigbaum J (2018) Earliest isotopic evidence in the Maya region for animal management and long-distance trade at the site of Ceibal, Guatemala. Proc Nat Acad Sci 115:3605-3610. https://doi.org/ 10.1073/pnas.1713880115

Sharpe AE, Inomata T, Triadan D, Burham M, MacLellan J, Munson J, Pinzón F (2020) The Maya Preclassic to Classic transition observed through faunal trends from Ceibal. Guatemala PLOS ONE 15:e0230892. https://doi.org/10.1371/journal.pone.02308 92

Sharpe AE, Smith-Guzmán N, Curtis J, Isaza-Aizpurúa I, Kamenov GD, Wake TA, Cooke RG (2021) A preliminary multi-isotope assessment of human mobility and diet in pre-Columbian Panama. J Archaeol Sci Rep 36:102876. https://doi.org/10.1016/j. jasrep.2021.102876

Sharpe AE, Arroyo B, Estrada J, Ajú G, Serech E (2022) Dogs for the gods, fish for the feast: the ceremonial role of animals at Kaminaljuyu, Guatemala. Lat Am Antiq 1-21. https://doi.org/ 10.1017/laq.2021.81

Shook EM, Kidder AV (1952) Mound E-III-3, Kaminaljuyu, Guatemala. Contrib Am Anthropol Hist 53:33-127

Somerville AD, Schoeninger MJ, Braswell GE (2016) Political alliance, residential mobility, and diet at the ancient Maya city of Pusilha, Belize. J Anthropol Archaeol 41:147-158. https://doi. org/10.1016/j.jaa.2015.11.004

Somerville AD, Froehle AW, Schoeninger MJ (2018) Environmental influences on rabbit and hare bone isotope abundances: implications for paleoenvironmental research. Palaeogeo Palaeoclim Palaeoecol 497:91-104. https://doi.org/10.1016/j.palaeo.2018. 02.008

Somerville AD, Nelson BA, Punzo Díaz JL, Schoeninger MJ (2020) Rabbit bone stable isotope values distinguish desert ecoregions of North America: data from the archaeological sites of Pueblo Grande, La Ferreria, and La Quemada. J Archaeol Sci 113:105063. https://doi.org/10.1016/j.jas.2019.105063

Sponheimer M, Lee-Thorp JA (1999) Oxygen isotopes in enamel carbonate and their ecological significance. J Archaeol Sci 26:723728. https://doi.org/10.1006/jasc. 1998.0388

Stone AJ, Zender M (2011) Reading Maya art: a hieroglyphic guide to ancient Maya painting and sculpture. Thames \& Hudson, London

Sugiyama N, Fash WL, France CAM (2018) Jaguar and puma captivity and trade among the Maya: stable isotope data from Copan. Honduras PLOS ONE 13:e0202958. https://doi.org/10.1371/ journal.pone. 0202958

Sugiyama N, Martínez-Polanco MF, France CAM, Cooke RG (2020) Domesticated landscapes of the neotropics: isotope signatures of human-animal relationships in pre-Columbian Panama. J Anthropol Archaeol 59:101195. https://doi.org/10.1016/j.jaa. 2020.101195

Tieszen LL, Fagre T (1993) Effect of diet quality and composition on the isotopic composition of respiratory $\mathrm{CO} 2$, bone collagen, bioapatite, and soft tissues. In: Lambert JB, Grupe G (eds) Prehistoric human bone-archaeology at the molecular level. Springer-Verlag, Berlin, pp 121-153. https://doi.org/10.1007/ 978-3-662-02894-0_5

Thornton EK (2011) Reconstructing ancient Maya animal trade through strontium isotope $\left({ }^{87} \mathrm{Sr} /{ }^{86} \mathrm{Sr}\right)$ analysis. J Archaeol Sci 38:3254-3263. https://doi.org/10.1016/j.jas.2011.06.035

Thornton E, Emery KF, Speller C (2016) Ancient Maya turkey husbandry: testing theories through stable isotope analysis. J
Archaeol Sci Rep 10:584-595. https://doi.org/10.1016/j.jasrep. 2016.05.011

Valdés JA (1997) El Proyecto Miraflores dentro del marco preclásico de Kaminaljuyu. In: Laporte JP, Escobedo HL (eds) X Simposio de Investigaciones Arqueológicas en Guatemala, 1996. Museo Nacional de Arqueología y Etnología, Guatemala City, pp 81-91

Valdés JA, Popenoe de Hatch M (1996) Evidencias de poder y control social en Kaminaljuyu: Proyecto Arqueológico Miraflores II. In: Laporte JP, Escobedo HL (eds) IX Simposio de Investigaciones Arqueológicas en Guatemala, 1995. Museo Nacional de Arqueología y Etnología, Guatemala City, pp 377-396

Valdés JA, Wright LE (2004) The Early Classic and its antecedents at Kaminaljuyu: a complex society with complex problems. In: Bell EE, Canuto MA, Sharer R (eds) Understanding Early Classic Copan. University of Pennsylvania Museum of Archaeology and Anthropology, Philadelphia, pp 337-355

van der Merwe NJ (1982) Carbon isotopes, photosynthesis, and archaeology: different pathways of photosynthesis cause characteristic changes in carbon isotope ratios that make possible the study of prehistoric human diets. Am Sci 70:596-606

van der Merwe NJ, Tykot RH, Hammond N, Oakberg K (2000) Diet and animal husbandry of the Preclassic Maya at Cuello Belize: isotopic and zooarchaeological evidence. In: Katsenberg MA, Ambrose SH (eds) Biogeochemical approaches to paleodietary analysis. Kluwer Academic/Plenum Publishers, New York, pp 23-38

von Koenigswald W (1985) Evolutionary trends in the enamel of rodent incisors. In: Luckett WP, Hartenberger JL (eds) Evolutionary relationships among rodents: a multidisciplinary analysis. NATO ASI Series. Springer, Boston, pp 403-422

Whisson D, Villa-C B (1996) The pocket gopher as a pest in Mexico. Proc Seventeenth Vert Pest Conf 57:151-153

White CD, Healy PF, Schwarcz HP (1993) Intensive agriculture, social status, and Maya diet at Pacbitun, Belize. J Anthropol Res 49:347-375. https://doi.org/10.1086/jar.49.4.3630154

White CD, Spence MW, Longstaffe FJ, Law KR (2000) Testing the nature of Teotihuacan imperialism at Kaminaljuyu using phosphate oxygen-isotope ratios. J Anthropol Res 56:535-558. https://doi.org/10.1086/jar.56.4.3630930

White CD, Pohl MD, Schwarcz HP, Longstaffe FJ (2001) Isotopic evidence for Maya patterns of deer and dog use at Preclassic Colha. J Archaeol Sci 28:89-107. https://doi.org/10.1006/jasc. 1999.0560

White CD, Pohl MD, Schwarcz HP, Longstaffe FJ (2004) Feast, field and forest: deer and dog diets at Lagartero, Tikal, and Copan. In: Emery KF (ed) Maya zooarchaeology: new directions in method and theory. UCLA Press, Los Angeles, pp 141-158

Wing ES (1981) A comparison of Olmec and Maya foodways. In: Benson E (ed) The Olmec and their neighbors. Dumbarton Oaks, Washington, pp 20-28

Wright LE (2012) Immigration to Tikal, Guatemala: evidence from stable strontium and oxygen isotopes. J Anthropol Archaeol 31:334-352. https://doi.org/10.1016/j.jaa.2012.02.001

Wright LE (2013) Examining childhood diets at Kaminaljuyu, Guatemala, through stable isotopic analysis of sequential enamel microsamples. Archaeom 55:113-133. https://doi.org/10.1111/j. 1475-4754.2012.00668.x

Wright LE (2017) Oxygen isotopes. In: Gilbert AS (ed) Encyclopedia of geoarchaeology. Springer, Dordrecht, pp 567-574. https://doi. org/10.1007/978-1-4020-4409-0_22

Wright LE, Schwarcz HP (1998) Stable carbon and oxygen isotopes in human tooth enamel: identifying breastfeeding and weaning in prehistory. Am J Phys Anthropol 106:1-18. https://doi.org/ 
10.1002/(SICI)1096-8644(199805)106:1\%3c1::AID-AJPA1\% 3e3.0.CO;2-W

Wright LE, Schwarcz HP (1999) Correspondence between stable carbon, oxygen and nitrogen isotopes in human tooth enamel and dentine: infant diets at Kaminaljuyú. J Archaeol Sci 26:11591170. https://doi.org/10.1006/jasc.1998.0351

Wright LE, Valdes JA, Burton JH, Price TD, Schwarcz HP (2010) The children of Kaminaljuyu: isotopic insight into diet and long distance interaction in Mesoamerica. J Anthropol Archaeol 29:155-178. https://doi.org/10.1016/j.jaa.2010.01.002
Kaplan J (2002) From under the volcanoes: the ideology of rulership at Late Preclassic Kaminaljuyu. In: Love MW, Popenoe de Hatch M, Escobedo HL (eds) Incidents of archaeology in Central America and Yucatan: essays in honor of Edwin M. Shook. University Press of America, Lanham, pp 311-358

Publisher's note Springer Nature remains neutral with regard to jurisdictional claims in published maps and institutional affiliations. 